\title{
Fashion Design Education and Sustainability: Towards an Equilibrium between Craftsmanship and Artistic and Business Skills?
}

\author{
Monika Murzyn-Kupisz ${ }^{1, *(\mathbb{D})}$ and Dominika Hołuj ${ }^{2}$ (D) \\ 1 Institute of Geography and Spatial Management, Jagiellonian University, Gronostajowa 7, \\ 30-387 Krakow, Poland \\ 2 Institute of Spatial Development and Urban Studies, College of Public Economics and Administration, \\ Krakow University of Economics, Rakowicka 27, 31-510 Krakow, Poland; holujd@uek.krakow.pl \\ * Correspondence: monika.murzyn-kupisz@uj.edu.pl
}

Citation: Murzyn-Kupisz, M.; Hołuj, D. Fashion Design Education and Sustainability: Towards an

Equilibrium between Craftsmanship and Artistic and Business

Skills? Educ. Sci. 2021, 11, 531.

https://doi.org/10.3390/

educsci11090531

Academic Editor: Naomi T. Krogman

Received: 15 July 2021

Accepted: 7 September 2021

Published: 10 September 2021

Publisher's Note: MDPI stays neutral with regard to jurisdictional claims in published maps and institutional affiliations.

Copyright: (c) 2021 by the authors. Licensee MDPI, Basel, Switzerland. This article is an open access article distributed under the terms and conditions of the Creative Commons Attribution (CC BY) license (https:// creativecommons.org/licenses/by/ $4.0 /)$.

\begin{abstract}
Fashion designers can have a key role to play in making fashion more sustainable, as they are able to influence and contribute to all dimensions of fashion impact (economic, environmental, social, and cultural), both positive and negative. Fashion design education should be seen as a chance to make aspiring designers aware of the challenges and potential of design for sustainability and equip them with the knowledge and skills necessary to implement sustainable fashion approaches. Starting from this premise, the approach to various sustainability themes was examined in the particular national context of post-secondary schools offering fashion majors in Poland, one which so far has not been researched in any depth. The authors conducted interviews and analysed the publications, documents, web pages, and Facebook profiles of such schools. Their activities were examined and classified in respect of the main dimensions of comprehensive fashion education: art, craftsmanship, and business. The analysis provides a picture of the current situation and a review of the specific features of sustainable fashion education in both the global and Polish contexts. Contemporary fashion education requires multidimensional adjustments to curricula, reflecting the complex nature of sustainability problems. This is a global challenge, which in the Polish case is additionally exacerbated by insufficient and uncoordinated public support, problems related to the institutional context of private and public schools, and the low level of sustainability awareness among consumers.
\end{abstract}

Keywords: education for sustainability; sustainable design education; fashion schools; sustainable fashion

\section{Introduction \\ 1.1. The Complex Challenges of Sustainability in the Fashion Sector}

In recent decades, there has been a growing awareness of the fact that the fashion industry is a particularly unsustainable and environmentally harmful sector of the economy [1-3]. There are also significant social and ethical problems that can be traced back to certain aspects of fashion production and consumption [4]. The design, production, and consumption of fashion and apparel is, therefore, strongly linked to broadly understood sustainable development challenges and their various dimensions, ranging from the ecological to the socio-economic and cultural. In response to these challenges, diverse approaches have emerged with the view of making fashion more sustainable [1,2,4-8].

The discussion regarding sustainable fashion initially concentrated on mitigating the harmful impacts of the industry on the natural environment, focusing on the production and use of particular types of textiles, minimising consumption of resources, modifying the production process (e.g., with regard to the use of certain chemical substances), efficient use of fabrics (zero waste), and their reuse (recycling and upcycling), more recently under 
the broader heading of a circular economy $[3,9,10]$. Over time, the understanding of sustainability in the fashion context has broadened to include social and ethical issues (working conditions and safety in sweatshops, fair trade, and the social responsibility of the fashion sector) and the organisation of production and responsible consumption (swapping, sharing, collaborative consumption, mending, reusing, limiting fashion purchases, and ecological attitudes with respect to clothing maintenance and laundering). The design and craftsmanship quality of garments has also begun to be highlighted, including the quality of the sewing, the flexibility and adaptability of designs, adjusting the design to particular physical or emotional needs, a slower pace of fashion in terms of shorter production chains, local production, making use of local skills and craft traditions, and embedding designs in regional culture and heritage. The design and production of clothing in the spirit of sustainable fashion can take the form of a smaller scale of production using more durable, better-quality fabrics in cooperation with local manufacturers, production on demand and made-to-measure, or design and production of clothing with a specific social meaning, rooted in and inspired by particular cultural considerations. Kate Fletcher [2] (xviii) therefore offered the following definition: 'sustainability in fashion and textiles fosters ecological integrity, social quality and human flourishing through products, action, relationships and practices of use'.

There are sustainability principles in the field of fashion that can be implemented by all stakeholders and market participants, and all of its segments (from independent designers to mass production, and from luxury to inexpensive supermarket fashion), and can impact all stages of the product lifecycle and fashion supply chain-from the initial product conception, through its production and distribution, to consumption and disposal. For instance, an estimated $80 \%$ of the environmental cost of a product is determined at the design stage [11] (p. 134). As designers are by definition involved in the initial conceptual phase of product development, and can, hence, impact all subsequent phases of fashion production and use, it has been noted that they can play a key role in making fashion more sustainable They are able to contribute, in both positive and negative ways, to fashion's impact on the environment.

The approach to the specificity and range of possible tasks faced by or undertaken by designers in this respect has likewise evolved and become more complex in the last two decades. Two main approaches to the sustainability of fashion design can be distinguished [12]. The first is referred to as the technocentric design approach and focuses on designers' involvement in minimising the negative impacts of the current setup of the fashion industry, with key words including recalibrating, repairing, and refining the existing systems of production and particular stages of a garment's lifecycle (focused on innovation in fibre types, supply chain management, and recycling). However, such 'a risk-reduction approach often puts in place restrictions to solve problems, while accepting the underlying conditions that created them' [13] (p. 234). The second approach, referred to as eco-centric, or design for sustainability, calls for a much deeper engagement of designers in the redefinition and rethinking of the fashion system, questioning the traditional market economy and production and consumption paradigms. From this point of view, as posited by Fletcher [12] (pp. 566-567), designers may benefit from 'opportunities to engage with sustainability that go beyond individual products or product lifecycles to include functional innovation, systems change, and redesign of consumer practices, behaviour, and even lifestyles'. These newer design-for-sustainability themes include, among others, co-design, design for empathy, design for changing socio-cultural norms, design for localism, slow design [14], and design for alternative economic and business models. If the first approach is understood as weak and reactive sustainability in design, the latter is perceived as stronger, proactive, and anticipatory, digging deeper into the setup and rationales of the fashion sector and thus more likely to bring a new vision to bear. It advocates a broader perspective on sustainable design, from 'materials and processes, to products and use, services and systems, business and strategies, and culture and experience' [15] (p. 113). 


\subsection{The New Roles of Fashion Designers}

This ties in well with the new roles envisaged for fashion designers as agents or even leaders of societal change, and with fashion's perceived potential as a tool for such change, especially from a postgrowth perspective. Transforming fashion design practices is, hence, seen as an important part of making fashion sustainable $[5,16,17]$. Designers do not simply 'shape material goods for sale' [11] (p. 134). They are not merely 'aesthetic providers', but should also be seen as practitioners who approach 'the design process with deeper levels of empathy, sociological pattern-recognition, innovation, and big picture capabilities' [18] (p. 193). As proposed by Kate Fletcher and Lynda Grose [5], they are to be communicatoreducators (sharing their knowledge and spreading it to firms, customers, and the general public), facilitators who help to change attitudes and production and consumption patterns (e.g., as facilitators of co-design, swapping, hands-on experience for users, or engaging with the public about their relationship with clothing), activists (e.g., working and engaging with non-governmental organisations, particular fashion brands, and governments), and entrepreneurs (innovating, implementing, and integrating sustainability in professional practice as independent designers or employees of larger organisations, developing new business models, and engaging in communication on fashion).

\subsection{The Need for Change in Fashion Design Education}

Academics and education institutions $[19,20]$ are seen as important elements of the circular economy. In light of this, the discussion on the sustainabilisation and ecologisation of fashion should naturally encompass fashion design education, in particular at the postsecondary level. Fashion design education can be seen as a way to shape and prepare young fashion designers, to make them aware of challenges and possibilities, and equip them with the knowledge and skills necessary to implement sustainable fashion approaches in their professional practice and to function in an increasingly volatile professional world more generally [18]. Design education may, therefore, be used as 'an essential tool for creating an ethical fashion system' [21] and to generate social change.

Studies on fashion design education from the perspective of the introduction of sustainable fashion issues into the activities and curricula of fashion schools are relatively numerous, but have so far focused on Western Europe (e.g., Great Britain, Scandinavia, and Italy) (e.g., [22-25]), East Asia (e.g., South Korea, Singapore, and India) [18,26], or nonEuropean Anglo-Saxon countries (the United States, Australia, and New Zealand) [11,27]. In the Polish context, the few existing studies on sustainable fashion have mainly pertained to the demand side of the market-attitudes and behaviours of fashion consumers or activities of particular brands [28-30] —rather than offering a broader picture of fashion education. This seems to be a research gap, as although Polish fashion design schools may not be pioneers in the introduction of sustainable fashion education, and Poland itself might be regarded as a post-colonial, semi-peripheral country both in terms of the delayed and less extensive implementation of sustainability ideas in general and the discussion of fashion sustainability in particular, for over a decade, sustainable fashion has been a theme with an increasing presence in the educational, promotional, and awareness-raising activities of post-secondary schools in Poland. Inclusion of references to sustainability in fashion design education in Poland followed the publication of the first educational materials, such as guidebooks and textbooks for students, designers, and businesses, both translated and written by Polish authors connected with pro-ecological non-governmental organisations and fashion schools. Moreover, changes in fashion design education should be seen within the broader context of the evolution of higher education from being knowledgetransmission-oriented to problem-solving- and soft-skills-centred, and from teaching to learning by tapping into multidisciplinary knowledge [31]. An analysis of the inclusion of sustainability in fashion design education may, therefore, offer a window into the broader issues of sustainability education and cultural and societal changes taking place in particular countries [24]. 
In light of the above, the aim of this work is twofold. Firstly, our goal is to conceptualise the dimensions of sustainable fashion education from the point of view of the education of fashion designers at the post-secondary level. Secondly, we intend to apply the conceptual framework to assess the status quo, trends, tensions, and challenges in sustainable fashion education for aspiring fashion designers in the Polish context. Two main research questions were posed: (1) What aspects and themes of education-related activities conducted by higher education institutions in Poland include sustainable fashion or ecological issues in fashion design, production, and consumption? (2) What are the challenges, difficulties, and problems experienced by lecturers and educators in fashion majors in Poland in terms of teaching sustainable fashion?

The structure of the article is as follows. These introductory remarks are followed by a section on the importance of a multidisciplinary approach and sustainability in fashion education. Next, the research design and methodology of this study on Polish fashion schools are presented. The empirical part of the text is structured according to the three main dimensions of fashion education: (1) artistic, (2) craft and vocational skills, and (3) business and entrepreneurship. The article concludes with a review of trends and challenges in fashion designer education in Poland, and sketches out future perspectives for research on the subject.

\section{The Importance of Sustainability in Fashion Education: Literature Review}

2.1. Fashion Designers as Artists, Craftspeople, and Entrepreneurs or Employees in the Fashion Industry

As fashion is a 'hybrid phenomenon' that crosses disciplinary boundaries [23] and is a sector with a base in both aesthetics and the reality of production processes, it requires fashion designers to have diverse knowledge and skills: artistic and creative, technical and craft, and entrepreneurial $[3,18,25,26,32,33]$, in addition to abilities such as collaboration and synthetic thinking [13]. As summarised by Angela Finn and Kim Fraser [27] (p. 1): 'Fashion design is not just about drawing pretty pictures but is rather an entire process that encapsulates conceptual design ideas and technical processes within the context of a target market.' It has also been noted that in order to practice sustainability and be successful from both a creative and economic point of view (to 'survive' in the market), designers have to integrate diverse skills and 'synthesize craft and garment making with scientific knowledge about people, culture, information and society' [18].

\subsection{Value-Based Learning}

A state-of-the-art fashion design education should, thus, reflect the complex nature of fashion. There is a need to develop programmes that place design in the context of the knowledge-based economy and that offer a deeper understanding of the complexity of the world and the connection between design and other spheres of life [18]. Paula Bertola [24] stressed the need to move from a 'products and designer' focus to stressing 'values and [the] design process' in fashion education, in an approach which should be multidisciplinary and project-based [26]. Timo Rissanen [34] proposed that fashion design education, in particular where sustainability is concerned, should be seen as leadership development. In this context, leadership is understood as the ability to create and inspire visions, exemplify and motivate behaviours, bring about desirable changes, and inspire cooperation [35]. Fashion's paradigm shift has to be parallel to fashion education's paradigm shift, in particular in terms of change towards reflexive learning [36].

\subsection{The Inclusion of Sustainability-Related Themes in Fashion Design Education}

Environmental sustainability and social responsibility are important topics relatively recently introduced into fashion design education at the higher education level, in response to current local and global concerns [37]. Initially, the inclusion of sustainable fashion themes in the educational activities of leading fashion schools in Western Europe and AngloSaxon countries mainly consisted of individual projects and elective, extracurricular courses. 
This was followed by the increasingly frequent inclusion of such topics in compulsory curricula at fashion schools worldwide (both as discrete courses and as an integral part of more general courses) and, in some (though still relatively rare) cases, the initiation of specific sustainable fashion-oriented fashion design programmes. Seminal initiatives of this type, which developed in the late 1990s and early 2000s, were followed by a growing number of activities in the last two decades [11].

As mentioned above, 'sustainability' in fashion design may pertain to diverse areas, including waste, substitution, or consciousness [38]. The various goals for the inclusion of sustainability issues in curricula, therefore, include making students aware of and understand various issues and challenges linked with sustainability across the product lifecycle and with respect to the fashion market as a whole, and developing their research skills and their ability to critically assess and reflect on the functions and impacts of fashion in the contemporary world and to test and implement a range of approaches [11]. Sustainable fashion design curricula may include various related issues, such as teaching the incorporation of tacit and haptic knowledge of textiles into fashion expression (textile thinking) through students' engagement in producing textiles [25,33], introducing students to different aspects of experimental 'smart' materials and garments (e.g., multisensory, empathic, or bio-smart clothes) [39], or assigning students various zero-waste design projects [40]. A range of approaches, such as collaborative learning, the integration of technology into the teaching and learning process, and connection and cooperation with industry, are applied [26]. The experiential and reflective nature of students' 'productive' encounters with sustainable fashion is often stressed [11]. It is argued that the educational process should approach sustainability as a complex, systemic issue that is multidimensional and requires change in organisational and learning processes [41].

Diverse positive effects of the inclusion of sustainability issues in design curricula have been noted. Notably, it leads to the development of a critical stance towards the professional roles and missions of designers, and it creates additional fruitful motivation for students: 'we see that sustainability often provides purpose, which spurs students to bring their design work to a higher level' [11] (p. 143). Such incorporation can also help students understand that working as a designer is not only a pleasure linked with implementing one's creative ideas but also a socially useful—albeit challenging-creative struggle [42].

\subsection{Limitations and Challenges of Sustainable Fashion Education}

Publications on fashion design education for sustainability note various challenges encountered at fashion schools. Despite the importance of the issue, sustainability-focused or related courses are mainly offered as electives [43]. Most often, 'sustainable fashion is viewed as an added competency, rather than as a core element within the different fashion education programs' [36] (p. 1). The fashion sustainability discourse may be unrealistic and superficial; it often polarises stakeholders, and may offer a simplistic understanding of solutions and identification of solution holders [44]. In fact, some authors identify fashion education itself as one of the generators of sustainability problems in fashion [36].

Course intentions and outcomes do not always correlate [22]. Not all students will fully comprehend the complexity of sustainability and espouse its principles or implement them in practice [11]. The size of student groups and teaching time constraints are additional important challenges to effective stimulation of reflection among students [22]. Moreover, graduation ultimately means that students have to find a way to make a living in their profession. Even if they develop an awareness of sustainability principles, they may end up working for unsustainable employers [11,22]; even assuming that they have a well-intentioned employer, they may experience challenges in applying a comprehensive sustainable approach, because in most clothing and apparel companies, the role of designers is still understood in a narrow way, i.e., as that of fashion stylists [11]. This clashes with the call for a broader approach to the design process as not simply garment-making [18]. 
Teachers encounter difficulties in training aspiring designers for an uncertain future that is not fully imaginable, in terms of either challenges or opportunities [18,45]. They have to prepare students for the complex, challenging, and volatile reality of the profession, but also encourage them to become responsible in their professional practices [22]. There is a constant need to update and modify curricula to include new-sometimes not fully tested-developments and inspirations $[25,26]$. It is not easy to encourage the spirit of openness, collaboration, and experimentation advocated as conducive to teaching sustainable fashion [24]. Activities should also be tailored to include cultural and national context-specific knowledge [26]. Schools' administrative structures may present a further obstacle, since teaching sustainability often requires cross-disciplinary and cross-faculty collaboration. Fashion design education still frequently continues to follow 'industrial fashion education', which tends to be linear, i.e., viewing each stage of fashion production and its different impacts as separate [36] (p. 3).

Not all faculty members may be convinced and fully supportive of sustainable fashion approaches, and they may rely on outdated teaching methods or have insufficient knowledge and experience, requiring training in sustainable fashion themselves $[11,18,26]$. Teachers may find it difficult to transcend disciplinary boundaries and the constraints of past experiences and knowledge and to remain open to new ideas and opportunities. According to Rissanen [45] (p. 543):

Design educators should be guardians of possibility and guardians of the possibility of possibility (... ) Too often design, including fashion design, is reduced to the creation of new products within the existing world, which we are expected to accept as is (...) Absolutely, we must learn from the past, but we must always move forward (... ).

A similar opinion is expressed by Bertola [24] (p. 12):

\begin{abstract}
A large majority of design and applied art institutions, in fact, focus on the old concept of product-centred education, feeding an enduring demand in prospective students, who are usually fascinated by fashion for its media and social impact, driven by individualism and not pragmatically informed by the professional context of designing and developing real products in a dramatically changing world.
\end{abstract}

\title{
3. Research Design and Methodology
}

\subsection{Identification of Post-Secondary Schools Offering Fashion Majors in Poland}

Following a literature review and the first conceptual phase of this research, the authors created an inventory of all Polish post-secondary schools that taught fashion design majors in the 2019-2020 academic year. After verification of the Ministry of Education and Science's list of schools offering such majors, eighteen universities and private higher education institutions were identified. They included five traditional arts institutions, namely the Academy of Fine Art in Krakow (AFAK), the Strzemiński Academy of Art Lodz (SAAL), the Academy of Fine Arts in Warsaw (AFAW), the Academy of Art in Szczecin (AAS), and the University of Arts in Poznan (UAP). The second group of schools offering education in fashion design were specialist private institutions focused on fashion design, such as VIAMODA University and the International School of Costume and Fashion Design MSKPU in Warsaw (MSKPU), the Cracow School of Art and Fashion Design in Krakow (CSAFD), and the Fashion School (FS) and the School of Form (SF) in Poznan (the latter school relocated to Warsaw in October 2020). In addition, this includes departments, chairs, and majors in fashion at universities and other higher education institutions with a broader artistic, technical, or general profiles, including private schools such as the Studio of Art (SA) in Warsaw and the Lublin School of Art and Design (LSAD), the Academy of Film, Art and Design in Lodz (AFAD), the Poznan University of Social Sciences (PUSS), and the University of Technology in Katowice (UTK). Public universities offering a broad range of majors such as the Lodz University of Technology (LUT), the Jan Kochanowski University of Kielce (JKUK), and the University of Technology and Humanities in Radom (UTHR) also included fashion majors and specialisations. (The abbreviations of the school names 
introduced here will be used throughout the text). Fashion education at the post-secondary level is concentrated in major urban centres, with particular visibility in the capital city of Warsaw, Lodz (which has been a major centre of the textile and fashion industry in Poland since the 19th century), Krakow (Poland's second-largest city and a major artistic and cultural centre), and Poznań (an important larger city with both a textile industry history and strong trade fair traditions, including the largest business-to-business fashion trade fair in Poland) (Figure 1).

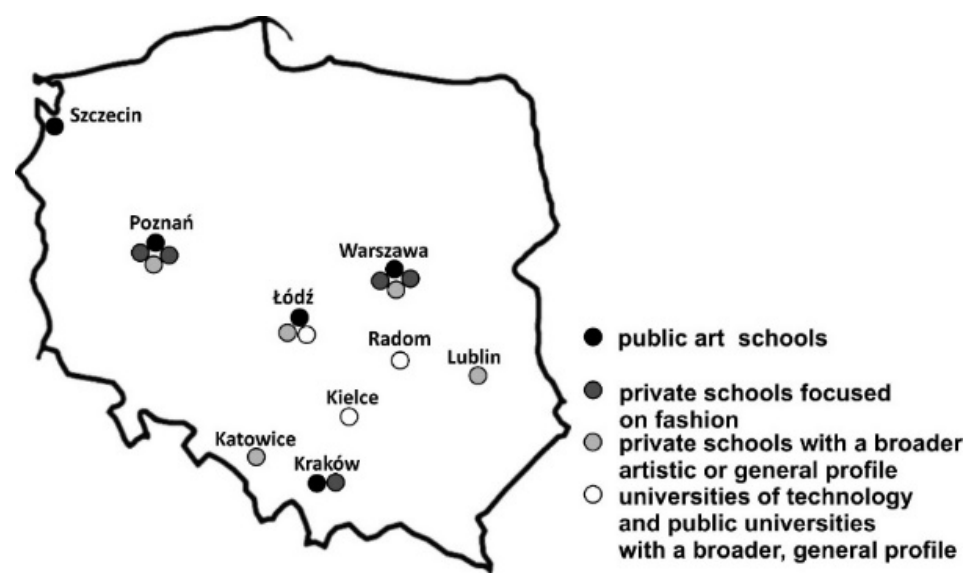

Figure 1. Higher education institutions offering fashion majors and specialisations in Poland in the 2019-2020 academic year. Source: Own elaboration.

\subsection{Interviews}

The next stage of the research focused on interviews, intended as an integral part of the investigation, to explore and explain the trends uncovered through the desktop research. In the period from March 2020 to May 2021, the authors conducted ten in-depth semi-structured interviews with individuals involved in the education of fashion designers at the post-secondary level. The group of interviewees was selected for diversity both in terms of their connections with fashion schools based in different cities, their professional experiences, and their own education, and also in terms of the types of courses they could offer to fashion students (fashion designers and experts with additional education in the fields of psychology, fashion ethics, management, fashion styling, fashion history, and specialisations linked to fashion marketing and retail). All the interlocutors were currently (or had recently been) lecturers for at least one of the fashion schools, and two of them were directors of such institutions. In addition to their educational endeavours, they were involved in diverse fashion-related activities, such as managing their own fashion brands (4); managing sustainable fashion stores with new or vintage fashion (3); running sustainable fashion blogs (3); and/or organising sustainable fashion events (2). Six out of ten were trained as professional fashion designers, and the others were fashion-related professionals, such as historians of fashion or fashion stylists. Some of them also had experience as specialists advising firms on corporate social responsibility (CSR) in fashion or working as personal shoppers. The majority were connected to specialist private fashion schools, though teachers representing public art schools and private schools with a broader profile were also interviewed. Due to the COVID-19 pandemic, the interviews were conducted online. Each interview lasted between two and four hours. The interviews were transcribed, anonymised and coded (codes I1 to I10) in chronological order.

\subsection{Main Themes and Dimensions of the Analysis}

The literature review and analysis of interviews with stakeholders in fashion education led to the identification of three interconnected dimensions of fashion design education, within which different aspects of education on sustainable and responsible fashion are included (Figure 2). These three dimensions represent the various multidimensional skills 
mentioned above required by fashion designers if a holistic approach is to be applied to their education and to training them to function in the professional world. A well-educated professional fashion designer should combine three types of skills: artistic and creative (crucial for the development of ideas and concepts for new garments), craft or vocational (much needed to 'translate' these ideas into actual pieces of clothing that are properly constructed, cut, and sewn), and entrepreneurial or business skills (enabling the designer to function effectively in the fashion market, to promote, distribute, and sell clothes or related services). Our interviewees stressed that fashion design education that neglects any of the above dimensions is incomplete and defective due to their interconnectedness and interdependence.

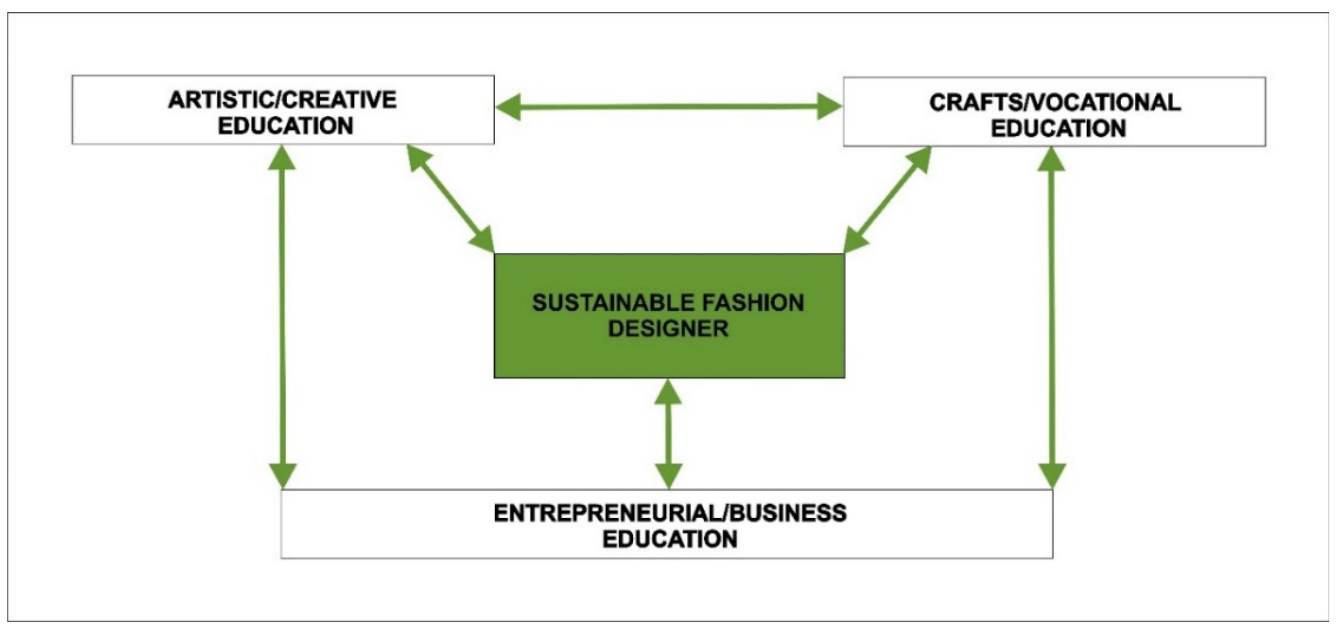

Figure 2. Dimensions of the sustainable fashion designer education process. Source: own elaboration.

Applying the above three-dimensional conceptual framework to the activities of Polish fashion design schools, the information, data, publications, and documents from the 18 schools were analysed, and the contents of their web pages and Facebook (FB) posts were examined. Our main hypothesis was that if a given school considers sustainability important, sustainable approaches to fashion would somehow be included, visible, and promoted in its activities, either explicitly in official statements and declarations or implicitly in its educational and other extracurricular activities. Moreover, the school would be promoting these activities on its web page or social media (FB) page. In addition, since fashion majors are offered by different types of schools, we supposed that specialist private schools focused on fashion would be more likely to engage in sustainable fashion education than other school types, both for organisational reasons (the ease of making changes to the curricula and implementing new ideas) and out of commercial concerns (as a way to promote themselves and prove that they are up to date with current trends in the fashion market).

In analysing particular schools, ten different facets of their inclusion of references to fashion sustainability in their activities (activity types and dimensions of analysis distinguished by the authors) were taken into account, both inward-oriented (intended for students either as compulsory or extracurricular) and outward-facing (offered to students but also to other fashion professionals and the general public), and conducted independently or in cooperation with other partners. These were as follows: (1) the mention of sustainability in official statements or other public communications (articles, blogs, podcasts, and manifestos); (2) sustainability as a leitmotif of the school curriculum (present in all courses or as a dedicated course); (3) inclusion of sustainability in student designs (created as assignments for particular courses or as a leitmotif of end-of-year or graduation collections); (4) organisation of sustainability-oriented activities and events compulsory for its students; (5) organisation of activities and events (e.g., conferences, workshops, and professional meetings) as an additional, extracurricular offer addressed to students or stu- 
dents and other (external) fashion professionals; (6) organisation of events (e.g., workshops) addressed to the general public (non-specialist participants unconnected with the fashion market); (7) publishing on sustainable fashion; (8) participation of school representatives (lecturers and students) in sustainable fashion events and initiatives organised by other institutions and organisations in Poland and abroad; (9) cooperation with other stakeholders in sustainable fashion initiatives (other schools, firms in the fashion industry, museums, and non-governmental organisations); and (10) promotion of sustainable fashion events and initiatives organised by other (external) bodies. A particular activity type was considered as undertaken by a given school if information on it was provided on a school's web page or FB page at least once in 2018-2020. Detailed investigation focused on information for this three-year period; however, in some cases, if activities that were important and especially novel and pioneering in the Polish context were undertaken prior to that period and were mentioned in the interviews, these were also included in the review.

\section{Results: Sustainability in the Education of Future Fashion Designers in Poland}

\subsection{Sustainability Education as a Part of the Artistic Dimension of Fashion Education}

Seeking out new creative impulses, aesthetic expressions, forms, and materials, discovering new artistic frontiers, and breaking down barriers are inherent elements of any creative profession. All the schools offering fashion majors and specialisations analysed here have an artistic profile; hence, developing creativity, artistic skills, and sensitivity are naturally fundamental aspects of their teaching and education philosophy. Students are confronted with the creative challenges necessary for their professional and artistic development and are encouraged to search for new inspirations, which may include references to fashion sustainability.

The fashion designs produced as a result of these artistic experiments and explorations during the period under study were mainly haute couture projects, sometimes also unique, original clothing intended for people who want to stand out, who desire to be visible and noticed. In creating the designs, different methods of limiting material use were applied (recycling, upcycling, and deconstruction), not only as a way to economise the creative process (lower cost of supplies) but also intentionally as an artistic activity with a pronounced environmental meaning. As one of the teachers mentioned, 'For me, a favourite way to pay homage to the environment each and every time is the never-ending recycling of the materials that we already have, which have already been produced' (I1).

\subsubsection{Creative Reuse of Textiles and Other Materials}

Many of the designs involved the reuse of natural leather and denim (e.g., projects by students at UAP in Poznań and MSKPU in Warsaw). The reuse and recycling of textiles and other materials in fashion design was presented to students as a means by which the fashion designer can express their concern for and responsibility towards natural resources and the environment (including respect for animals). Disposal of materials after using them only once is seen as a 'double' lack of ethics on the part of the fashion industry, which already exploits the natural environment in sourcing leather, furs, and natural silk. Students are shown that used materials which are in some way degraded, worn-out, or torn can be a much more interesting alternative for creative endeavours than new ones (e.g., faded textiles; I2). They are encouraged to think of non-conventional, out-of-the-box uses for materials (e.g., creating faux fur from unravelled yarn as a time-consuming process that enables the creation of an alternative to unethically sourced materials) (I1).

Classes on deconstruction are a way of developing student creativity, inspiring them to be open to non-standard approaches to clothing that has already been produced. They were encouraged to find solutions to design challenges such as transforming classic men's apparel (suits, coats, shirts, or smoking jackets) into female garments (one example was a design for a dress made of 20 men's shirts created at FS in Poznań). Similar tasks were given to students at CSAFD in Krakow and AFAW and VIAMODA in Warsaw. An important aspect of these tasks is not only to develop in future fashion designers particular technical 
skills or break down creative barriers, but also to inculcate an approach to fashion design as a process that requires reflection, patience, and diligence (I1).

Another way of introducing the issue of recycling materials in fashion education is to broaden the catalogue of materials used to include elements not directly connected with textile and garment production. Students created designs from used paper, such as used posters, newspapers, teabags (I2), or other paper waste (e.g., advertising banners, nutshells, twines, wood, or jute sacks) (FS).

\subsubsection{Socially Engaged Fashion}

Some of the tasks given to students were in line with the socially engaged art paradigm. The analysed schools stressed the role of the artist as both creator and promotor of this idea. This issue is reflected in a comment made by one of the interviewees: 'Fashion is not only an item of clothing. Fashion is an element of the system of culture and art and a language of visual communication' (I3). The web page of SA in Warsaw reads: 'The art we teach is for the benefit of the viewer. It is to bring pleasure to its audience but also inspire reflection. Art has the right to comment on the reality and sometimes "act" on the subconscious; it is not always only pleasant'. In a similar vein, in a recent issue of the artistic journal Tuba, published by CSAFD in Krakow, there is an article on artists who pursue artistic projects as a way to communicate their ecological views and stances [46].

\subsubsection{Rethinking the Philosophy of Fashion, Preparing Statements and Manifestos on Sustainable Fashion}

More complex projects incorporating a broad approach to fashion and its cultural, social, and economic functions were developed by those schools in which specific statements on ecological issues were communicated directly (FS, CSAFD). It is also important to mention that the organisation of such projects and their implementation was usually preceded by a discussion with students, both on the problems of the contemporary fashion market and on broader global ecological issues, as well as the role of the fashion designer in rendering fashion more ecologically friendly and responsible. The intention was to encourage students to reflect on such issues and consider the mission and responsibility of fashion designers to society from a personal perspective. This dimension of individual responsibility seems to be the most important and at the same time most difficult (though necessary) step that the would-be fashion designer needs to take: that of self-definition and self-understanding-followed by a public declaration of personal attitudes and viewpoints on the self, the world, and fashion consumers. For instance, at CSAFD, students were asked to create a public fashion manifesto as a guideline for their design activities and as a tool for communication with customers. The most important aspect of this task was the requirement to make the declaration credible and to share the statements in the manifesto with others, e.g., by posting it on social media.

The staff of fashion schools also participate or get involved in the development of such manifestos themselves, in order to stress the inevitability and the desired direction of change in the design and fashion market. One example of such activities is the participation of SF representatives in the programme board of the Gdynia Design Days. In one year, this involved developing a manifesto, setting out values that should guide designers in their work. This document proposed that contemporary designers deepen the relations between man and nature, concentrate on the common good, support economic development based on social welfare and not on a continuous growth paradigm, and work to develop the circular economy and ecological consumer orientations. CSAFD, in turn, used social media to encourage readers to familiarise themselves with the Designers' Manifesto published by Trendstudio, an organisation created by individuals with connections to the fashion market, including lecturers from CSAFD.

Student research and study groups functioning at particular schools were also involved in exploring and defining the desired relations between designers and the world. For instance, the Student Sculpture Group at the UAP in Poznan defines itself as follows: 'The group $(\ldots$ ) brings together students who are searching for their place not only in 
the art world but also in the reality surrounding them. Friendly and open social relations, and respect for nature and climate protection are necessary both for self-development and joint, common actions' [47]. Students in this study and research group have, for example, participated in an ecological project whereby a patchwork with eco-oriented slogans and texts was created. Their creative efforts addressing challenges of the contemporary fashion market are, therefore, not limited to designing clothing as such, but extend to using their fashion design skills for a range of purposes.

\subsubsection{Cultural Heritage as Fashion Inspiration}

An important element of artistic education connected with slow fashion is courses, lectures, workshops, and tutorials on the history of fashion, traditional and local materials, traditional craft techniques, and textile decoration and dyeing techniques. One of our interlocutors pointed out that although there have always been certain unethical aspects to fashion (e.g., use of leather, furs, and feathers), until the mid-20th century, the industry tended to be relatively sustainable in terms of the longevity and reuse of textiles and garments. As long as they retained some usable qualities, ways of reusing them were usually found in order to avoid waste of both materials and of the human effort required to process them into textiles (I3). Artistic inspirations derived from historic and traditional textiles, costumes, and clothing-both elite and humbler (e.g., vernacular and folk garments and textiles) - were used in the analysed schools in diverse ways and were also frequently present in their educational activities. A significant number of students who prepared fashion designs and collections for particular courses or as part of their final diploma based their designs on textiles created using traditional weaving techniques (e.g., a diploma collection using hand-made textiles prepared by the great-grandmother of one CSAFD student), using historical clothing (e.g., a collection prepared by an FS student using her grandmother's communist-era garments), or referring in form, detail, and decoration to period clothing or the heritage of certain ethnic groups (e.g., a collection prepared by a CSAFD student inspired by the Lemko culture from the south-eastern corner of contemporary Poland; a fashion collection inspired by Belarusian folklore at VIAMODA; a collection inspired by Mongolian folklore at LUT; a collection inspired by medieval clothing by a student from UAP; a collection referring to the folk costumes of the Bamber ethnic group from near Poznań; and a collection created at SF entitled 'Tradition and abstraction' that used handmade lace, embroidery, and macramé to refer to the potential of traditional crafts). Dedicated events were organised to highlight historic forms, textiles, and techniques, featuring presentations of students' endeavours (e.g., the exhibition Ethno-Retrospection. Slavic roots prepared by the Student Science Club at LUT). In order to broaden students' artistic horizons, they were also introduced to local traditional production and craftsmanship techniques that are not directly connected to fashion but could be used as inspiration, for instance, to create unique textiles (e.g., workshops with local traditional roofers in the Suwałki region of north-eastern Poland for students of the AFAW) (I3). Inspirations from nature and crafts were also visible in experimental textile development, for instance using raw tree sprigs and twigs (Experimental Textile Department at the AFAD).

Moreover, students are encouraged to search for inspiration for fashion projects in the oeuvres of Polish artists from different historic periods, representing a broader range of artistic disciplines. For instance, a project at the UAP's Department of Unique Fashion entitled 'Witkacy's Theatre of Fashion' required students to take the artistic creations of the prominent avant-garde Polish artist from the interwar period, Stanisław Ignacy Witkiewicz (nicknamed Witkacy), who used various artistic disciplines, such as visual arts, photography, theatre, and literature, as a point of departure for their designs. Some aspects of the teaching of the history of fashion and traditional crafts were implemented jointly with museums, making use of the potential of their collections as sources of design inspiration (e.g., cooperation between the AFAW and the National Museum and the State Ethnographic Museum in Warsaw). Sometimes, this cooperation involved fostering more 
complex international and interuniversity links (e.g., LUT is a partner in the CREATEX project for the promotion of European textile heritage as a source of inspiration for fashion designers-as part of this project, students develop textiles using motifs from Polish folk papercuts and local embroidery patterns from traditional folk costumes).

\subsubsection{Sustainability as a Leitmotif of Diploma Collections}

The recognition of and identification with the (pro)environmental role of designers was also visible in the diploma fashion collections created by fashion graduates and in the commentaries and descriptions accompanying these. One such was the diploma collection by Katarzyna Kwiatkowska and Natasza Rogozińska from SF entitled 'Entanglement', which aimed to bring attention to the overwhelming effect of possession of an excessive number of garments on contemporary humans. It was accompanied by the following comment: 'In a world of omnipresent consumption, clothes are bought in excessive quantities and become a prison for the body and the mind.' Another example is the diploma collection of Zuzanna Wójcik from AFAW, entitled 'Supernature', which was made from textiles with a minimal negative impact on the environment, such as banana, bamboo, eucalyptus, and lotus fibres, as well as others made from waste sourced from the dairy production process. Wójcik noted: 'The Supernature collection was created as the result of (personal) reflection on the problems of the contemporary world: climate change and environmental pollution. I have attempted to find solutions for a fashion for the future, so that it will no longer pose a threat to humans, to other species of animals and plants' [48].

\subsection{Educating for Sustainability as Part of the Craft and Practical Skills Dimension of Fashion Education}

Developing craft-related and practical vocational knowledge and skills-a crucial aspect of fashion collection development-is the next important dimension of fashion designer education identified by the authors. Practical vocational training in the schools under research is also to some extent connected with developing attitudes and stances regarding our responsibility to nature and man. Problems stemming from the instrumentalisation of design or a focus on design for design's sake, without a mission or a broader aim, which leads to exacerbation of the ecological (and ethical) crisis, were noted. As stated by one of the fashion professionals interviewed: 'Medics have the Hippocrates oath, but a designer can still design irresponsibly, e.g., single-use items, without any punishment' (I2).

Fashion design education, then, not only consists of developing practical knowledge but is also a long term, multidimensional process of shaping responsible attitudes to resources, nature, and man. As one lecturer put it, 'Design is not only manual skills but most of all a discerning outlook on the world and thinking! Focus on the client, on their needs, lifestyle, and requirements. Inclusion of current challenges and introduction of ecological and ethical solutions and technologies-only in this way can brands that stand out and collections that will be profitably sold emerge. This does not at all preclude creativity, sensitivity, and "playing" with fashion' [49].

4.2.1. Making Fashion Students Aware of Practical Sustainability Challenges and Possible Solutions

In practice, fashion design lecturers, teachers, and instructors face many challenges in this respect, even from the very beginning of the educational process. A large proportion of the students who decide to enter fashion design education have a rather naïve or incorrect image of the nature of the fashion designer's work. Their expectations are often shaped by stereotypes and the media. If they are aware of contemporary sustainability challenges and ecological problems linked with fashion, their knowledge is usually limited and superficial (I1, I2, I4, I8). In this context, fashion design education often needs to start by removing or destroying these unrealistic and dangerous preconceptions, showing the dilemmas inherent in fashion design work, and teaching how the fashion market functions: what its modes of operation and goals are, and to what extent they are in line or in direct conflict with sustainable development principles, in particular in the case of the fast fashion 
sector. Teachers in fashion majors may demonstrate particular issues connected with the fashion market in such a way as to stimulate emotions and cause reactions (e.g., by showing a multitude of telling images and statistics). Many of them stress that this first stage of making students more aware of existing problems and challenges is very difficult. It is a time of heated discussion that does not always lead to (the desired) educational outcomes. Not every young designer will be convinced to follow a more sustainable design paradigm, and long-term attitude change is possible only by discussing and showing the real 'face' of the profession and the market. The teacher's role is to present existing problems objectively, but also to set a good example by their own professional practice of incorporating sustainable fashion desiderata (learning by example). As one university faculty member commented, 'Students come to our school as blank notebooks. Throughout the entire period of their education, we write in these notebooks. My task is not to dictate their notes to them, heaven forbid sit down and write for them, [but rather] to direct the discussion in such a way to make them develop their own reflections' (I1).

After the 'awareness' stage discussing the current state of affairs and the 'sins' of the fashion market comes the next stage of shaping attitudes and building (practical) knowledge of how to minimise this negative socio-environmental impact of fashion in the students' own professional practices. The education of contemporary fashion designers, thus, also involves encouraging them to overcome problems and barriers to the implementation of different aspects of responsibility in fashion (e.g., how to desist from environmentally harmful, unethical textiles and design and production methods; how to distribute existing clothing; how to reduce pollution and limit resource use; how to design for flexibility and longevity; how to make use of previously created garments and the textiles they are made from; how to recycle and reprocess).

The higher education teachers of fashion majors we interviewed highlighted that the education of responsible fashion designers is a very complex process. One of the reasons for this is the multidimensionality of the damage and problems caused by the fashion market; another is the dynamic changes in the state of knowledge regarding the practice of responsible stances on fashion and its exponential growth in recent years. Moreover, teaching pro-ecological and responsible solutions cannot be superficial, because if it is, the achieved effects may paradoxically be diametrically opposite to those desired. For instance, it is not possible to teach about available materials and textiles with the conviction that any natural textile is more environmentally friendly than synthetic ones without taking into account the ecological costs of sourcing (e.g., cotton) or ethical issues (e.g., fur farming) (I4).

\subsubsection{Sustainable Selection and Use of Textiles, Minimising Textile Waste}

The very issue of teaching about textiles and materials, and problems regarding their selection and the means of using them, reflects the multidimensionality of the sustainability problem for designers. A comprehensive curriculum on this issue requires teachers to inform students not only of the ecological materials sourced naturally but also of those developed using modern technologies (e.g., furs and leathers produced in laboratories without the need to kill animals), and to broaden students' awareness of both the shortand long-term impacts of fashion (e.g., biodegradable materials) and the safety of using and wearing them (e.g., harmful substances present in textiles and clothing). A fashion designer should be aware of the provenance of textiles and materials they use and the ethics of their production (e.g., labour conditions and killing animals).

Many of the analysed schools teach design techniques that minimise textile wasteboth through the textile cutting techniques employed and by the reuse of existing garments and textiles (recycling, upcycling, and no-waste design). Some schools also encourage their students to experiment with production of ecological materials (e.g., making leather from fungi at MSKPU) or using natural dyes (I4). As part of the educational process, students create collections made of organic textiles (naturally or hand-dyed or painted), use biodegradable materials, produce their own textiles by growing or weaving them, 
and create new garments from recycled textiles (CSAFD, SF, MSKPU, AFAK, and FS). Techniques taught to students include not only reuse but also production to minimise waste (no-waste) and promotion of social-economy approaches to textiles (e.g., exchange and donation by designers and fashion firms of redundant or defective textiles, fabric scraps, and other materials to schools or other organisations that then make use of them).

In some schools, separate courses focused on no-waste issues are included in the compulsory curriculum (e.g., CSAFD, where the results of students' creative coursework are also presented during the Krakow Fashion Week; SF, with a project entitled 'Zero waste' in collaboration with a major Polish fashion producer). Another aspect of teaching is advising aspiring designers on how to prolong the use of clothes (e.g., more flexible clothes for children that adjust to their growing bodies). In addition, MSKPU organises a fashion design competition entitled the Responsible Fashion Awards, which focuses on issues of corporate social responsibility and ecological and ethical textiles. Entrants use ecological materials supplied by the organisers. One of the aims of this event is to promote new and eco-friendly fabrics, such as Tencel (lyocell), polyester from recycled PET bottles, modal, sorona, and a bio-based alternative vegan leather made from apple peel or other apple waste.

\subsubsection{Enhancing the Quality of Garment and Apparel Craftsmanship}

An important aspect of the education of responsible sustainable designers is shaping their attitudes towards the methods and quality of design and production ('If we are to make use of a fabric, create something from it, out of respect for it, let's do it well'; I1). Therefore, the interviewed teachers stressed the need to develop in young designers an awareness of the importance of the standard of the sewing and of the aesthetics of an entire project, including details such as stitches. High product quality and durability permit long-term use and may reverse negative trends by convincing consumers to rethink buying cheap, low-quality clothing [50]. Of course, such an approach is quite a challenge, in particular in times characterised by the dominance of fast fashion, and in a post-socialist country such as Poland, where past experiences (i.e., several decades of a communist economy of constant shortages) developed in generations of Poles the need to buy compulsively 'just in case', or because something is easily available. The relatively low prices of fast fashion coupled with growing purchasing power have exacerbated the problem in recent years (I3). The schools analysed here facilitate discussions on ways to reverse this trend. One way may be a return to closer ties and relations between end consumers (users of clothing) and their designers and producers-their involvement in the process of clothing creation. A longer, labour-intensive process of clothing production tailored to individual needs could translate into the (re)creation of an atmosphere of greater respect and appreciation for clothes and the people who produce them. This could, in turn, lead to a greater willingness to spend more on clothing but buy fewer items. For this process to happen, however, it was underlined that maintaining high standards and designing attractive, aesthetically pleasing clothing is vital. Only a combination of quality and aesthetic appeal can generate more loyal customers willing to appreciate items of clothing and use them for longer (I2).

\subsubsection{Awareness of Ethical Challenges Involved in Fashion Production}

Another important matter discussed in the context of fashion design education is ethical issues surrounding working conditions (e.g., in sewing rooms and sweatshops). These topics were mentioned during lectures and classes on CSR or design, for example. An important element of education to shape responsible attitudes in this respect is the involvement of fashion schools (e.g., CSAFD and MSKPU) in annual events organised all over the world, such as Fashion Revolution Day. Lecturers also get involved in promoting empathic attitudes towards textile and clothing industry workers by publishing on the topic (e.g., the publication in the Polish edition of Glamour of an article by a VIAMODA lecturer on working conditions in clothing factories). An important initiative at MSKPU in Warsaw is the statement in its statutory documents that students are forbidden to design 
using natural fur and leather for their school projects-as a way of communicating the ethical issues of using such materials. This question is also emphasised through events in which the school participates or that it co-organises. For instance, in cooperation with the Viva! foundation the school organised a fashion show, \#StopFurs, as one of the many actions it has undertaken jointly with organisations that campaign against fur farming [51]. On the occasion of this fashion show, it also compiled a free online publication entitled Empathy in Fashion. In addition, the school wrote an official petition to the president of Poland regarding a package of laws delegalising fur farming in Poland [52].

\subsubsection{Awareness of Special Needs of Particular Social and Age Groups}

Yet another aspect of the education of future designers is activities designed to make them more sensitive to the need to adjust and shape clothes in line with specific human needs (empathic design). Attention to the multidimensionality of users' needs and the need to humanise design were stressed both in class and in publications by particular teachers (e.g., Monika Rosińska, a sociologist and a lecturer at SF, published a book (in Polish) entitled Przemyśleć u/życie. Projektanci. Przedmioty. Życie społeczne (Rethink use/life. Designers. Objects. Societal life) [53], encouraging designers to pose and answer questions about why they create particular objects or items, for whom they are intended, and what and whose needs (the designer's or the user's) they should satisfy. Many of the schools analysed in the study highlighted that garments should meet not only the aesthetic needs of their users but also their health needs (e.g., an SF collection of hats from recycled fabrics for people with laryngological problems; the organisation by SAAL of a Gala Bra Day to support women fighting breast cancer; a CSAFD project using fabric scraps to create toys for patients at the local children's hospital) or changing needs arising from the aging process (e.g., VIAMODA's initiative to create clothing for seniors), or for a range of lifestyles and social issues (e.g., SF's project creating clothing for homeless people). Empathy in fashion is also understood as a willingness to react to urgent current needs. Here, the involvement of most fashion schools in sewing masks for medical staff in the early stages of the COVID-19 pandemic should be mentioned.

\subsubsection{Making Use of Local Heritage and Production Traditions}

The above-mentioned aspects of the ecologisation and 'sustainabilisation' of the fashion market are complemented by the inclusion of elements of slow fashion in the actual designs mentioned in the previous section (e.g., inclusion of design aspects that are hand-made or based on traditional forms of decoration, sewing, weaving, etc.), as well as searching for and encouraging the production of local fabrics rather than use of fabrics imported from distant places (for a lower carbon footprint and to support various sectors of the local economy). The implementation of this aspect of sustainable fashion is at once a means of regionalisation of production and a way to decrease its mass scale and repetitiveness. An example of a diploma project that tackled this problem is the graduation project by Sonia Kalandyk and Anna Pielesz, from AFAK, entitled 'Reacting to consumption - a model for a transparent brand of woollen accessories, Runo [Fleece]'. Its creators explained their reasons for selecting this topic for their diploma as follows: 'The shepherd culture and its values have become an inspiration [for us], in particular its frankness, honesty, simplicity, and respect for objects. The yarn used in our projects is wool, a local material, which is at present not appreciated, and wasted.' Other interesting projects include a competition launched by CSAFD and a global hotel chain encouraging students to design a staff uniform inspired by local history and traditions, and a fashion event organised by the Centre for Fashion Promotion at SAAL entitled Folk Fashion 2011: a fashion competition for young designers to find the best collection inspired by folk art and costumes produced in a prêt-à-porter form. 


\subsubsection{Designers' Potential to Impact Consumer Awareness and Choices}

A responsible designer aware of their own attitudes as a professional may also influence choices made by their customers. They work not only for clients who are aware of contemporary fashion and world problems but also for people who are less knowledgeable or even ignorant of these issues. Their work can, therefore, be a catalyst for changes in attitudes and growing awareness in fashion consumers [50].

\subsection{Educating for Sustainability as an Element of Business and Entrepreneurship Education 4.3.1. CSR in Fashion}

A good fashion design education also requires that students be equipped with a basic knowledge of entrepreneurship and how to develop and manage a firm or fashion brand, as well as knowledge that will enable them to communicate effectively while working for a larger organisation if they opt to work for a fashion producer or retailer with a more complex organisational structure. In both cases, they need some knowledge of management, the economics of enterprises, marketing, public relations, and CSR. An example of such an approach to fashion education is the mission voiced on the web page of the VIAMODA school: 'In our curriculum, special attention is paid to attuning the educational process to the real needs of the sector and updating detailed [curriculum] content to include trends constantly affecting the market and customer needs, but also to designing in line with the principles of sustainable development, product responsibility, high aesthetic standards, innovativeness, and the quality, ethics, ecology, and economics of the production and retail process' [54]. From the information obtained in the interviews, it is clear that in Poland the economic aspect of designers' education is still rather prone to neglect (I3, I6, I7), despite being a key factor for designers' survival in the market or fruitful cooperation within major fashion firms. Approaching fashion purely as a creative activity-the art of creating ideas for garments and costumes - may be detrimental to (in particular aspiring) designers' success (fashion brands that already function in the market, even if they lag behind in terms of modern management or marketing approaches, may survive or scrape by for some time by counting on loyal clients, but new ones have to break into the market) (I1, I2). This does not mean that fashion designers should follow separate specialist studies, but rather that they should have a basic knowledge and awareness of the factors, conditions, and limitations of the fashion market, of both a general and context-specific (e.g., national) nature. For instance, fashion brands in Poland may function differently in some ways than in other European countries or outside of Europe. The necessity and desirability of taking into account and adjusting to the local economic and social context was particularly stressed by interviewees, as fashion is a cultural phenomenon and, thus, is also spatially differentiated (I2, I3).

\subsubsection{Creating and Managing Sustainable Fashion Brands}

In order to help aspiring fashion designers develop entrepreneurial, business, and marketing knowledge and skills, fashion schools in Poland include the following issues in their curricula:

- Elaborating the development strategy of a fashion brand; developing marketing communication for the brand and its values, ideas, products, and their features (how to arouse customers' interest by selling them not only products but also the ideas behind them) and deciding on the desired target group-discerning their needs, devising ways of reaching them, and developing the skills and action needed to establish relations with potential clients (e.g., VIAMODA offered a series of lectures on marketing communication in fashion, with themes such as 'Responsible fashion and responsibly on fashion-how to create communication content for fashion products in line with the sustainable fashion paradigm?' [55];

- CSAFD published an article in its journal, Tuba, on the importance of marketing communication and the most efficient allocation of spending on it, stressing the need to inform potential customers about the product rather than, for example, investing a 
lot of money and effort in costly shows, and the necessity of planned communication with foreseeable timing in order to stay in regular touch with potential buyers and customers, as well as a predictable, repeated rhythm of release of new collections [56].

- It was similarly stressed that designers' responsibility for their own products and brands-also in terms of marketing communication-should always be implemented with empathy and respect for their clients and their situation (e.g., as a semester task at one of the interviewed schools, students were asked to analyse a recent advertising campaign by the Polish brand Medicine, which during the pandemic decided to run a controversial campaign with the motto 'Clothes can cure you' and was severely criticised, even by fast fashion consumers, for what was perceived as insensitive and irresponsible communication; I2). Sending misleading marketing communications is another problem (e.g., brands that sell garments made from natural fabrics and promote themselves as 'fully' responsible, even though their products are made from conventional cotton or natural silk). Schools' task is not only to make their students aware that such marketing signals are misleading but also to highlight their detrimental impact on consumers' awareness of real sustainability issues (I2).

- Creation of CSR strategies and ways of communicating them to co-operators and clients (e.g., MSKPU's emphasis on implementing a holistic CSR approach to design is evident in an original textbook on ethics in fashion published in Polish by the school's director, Magdalena Płonka [57]; the school and its staff also participated in events on CSR and sustainability-related issues such as the Business Fashion Environment Summit in Warsaw in 2020). It was stressed that developing brands founded on values, in particular in the context of reoccurring crisis situations in the market, makes it easier for such brands to better cope with challenges arising in difficult economic times (I2).

- Giving students skills and 'tools' - helping them to develop competencies to cooperate effectively within the organisational framework of a large fashion firm (e.g., cooperation with purchasing, marketing, or public relations (PR) departments).

- Making students aware that sometimes economic efficiency measures may be very much in line with sustainable fashion desiderata (for instance, designing clothes from fabric scraps or recycled textiles, minimising fabric waste) (I1, I2, I3).

At the same time, schools demonstrated awareness of evident economic dilemmas. These include issues directly related to the creative dimension of designers' work and the responsible limits of their (artistic) freedom (education on the adjustment of production plans to market demand (capacity) and the potential costs generated by poor decisions in this respect, such as the cost of storage and problems with the disposal of unsold production). The issues of product distribution and packaging were also discussed.

This aspect of fashion design education included discussions of salient trends in the market surrounding the inclusion of references to sustainability in the marketing strategies of a growing number of well-known international fashion brands. The duality of this phenomenon was noted and underlined. Some fashion brands are, indeed, shifting their operating philosophy towards more sustainable solutions. Others treat the sustainability trend as unavoidable and merely adjust their marketing to pay lip service to market trends (I2). For instance, in order to appear more connected with local production, some firms 'have employed the word "craft" in recent advertising' [58]. Still, this does not change the fact that in both cases (opting for an independent business or being employed by a larger fashion brand), young designers have to make their ideas and designs visible in the 'jungle' of other proposals and marketing messages, often engaging in difficult and unequal competition with large, well-known brands with big marketing budgets (I5). In most cases, the leitmotif and aim of the business and entrepreneurial education of aspiring fashion designers is, therefore, to increase their awareness of the scope and diversity of these problems, dealing with shallow stereotypes of how the market functions, and warning them of the dangers of developing superficial, unclear, or-even worse-false marketing communications. For instance, in the context of the contemporary Polish fashion 
market, this issue is of the utmost importance in light of several recent scandals linked with greenwashing and false information given to clients by brands marketing themselves as sustainable (CSAFD informed students of the tag and label scandals; VIAMODA offered a lecture entitled Fashionable Nonsense; I1), and dishonest practices by firms who, for instance, declare that their products are made from recycled fabrics (e.g., plastic waste from oceans), despite their prices precluding any real possibility of this. Schools stress that the damage to brand image generated by false, dishonest, or shallow marketing communication is hard to reverse. Even in Poland, where consumers are still insufficiently aware of sustainability issues in fashion or unconvinced of the need to adjust their consumption patterns in line with sustainability principles, such untrue statements and information are increasingly being exposed, publicly denounced, and scorned. In times of digital media, news travels very fast, so it is difficult, if not impossible, to keep inconvenient facts covered up. The same situation applies to greenwashing practices, where firms who merely pretend to follow sustainability principles rather than really implement them try to divert customers' attention from inconvenient facts about their harmful activities, or market themselves as responsible and deeply committed to CSR (I2, I3, I5). Creating a new responsible image without strong foundations does not work in the long term due to increased awareness among customers and the possibilities of modern communication to expose false messages mercilessly (I2).

\section{Conclusions}

\subsection{The Presence of Sustainable Fashion-Related Themes in the Activities of Fashion Schools in Poland}

Although Poland does not play a key role in the initiation and diffusion of sustainable fashion education approaches and functions as the receiving end rather than the generator of new ideas, in recent years, sustainability has become an issue with a relatively frequentalbeit incoherent and uneven-presence in the education of fashion designers. Sustainable fashion issues are present in all dimensions of fashion design education in Poland: artistic, vocational, and business-oriented. Perhaps it is least visible in the case of the latter, which so far is (on the whole) the least-developed dimension of fashion design education.

The analysis of interviews with experts and social media content confirmed the desirability of a holistic, three-dimensional approach to the education of fashion designers. This reflects a broader ongoing change in the approach to professional education in this field, both globally and specifically in the Polish context, from an initial focus mainly on the artistic dimension of designers' education towards a more integrated and balanced curriculum and instruction that puts equal emphasis on practical craftsmanship knowledge and skills, and finally acknowledging the indispensability of including entrepreneurial and managerial issues in the curriculum. The increasing recognition of the need for the integration of different skills in fashion education is also a good reflection of the desired evolution in the students' educational process. At the start, they are usually motivated by and focused mainly on developing their creative and artistic skills. With time, they are made aware of and introduced to technical and organisational issues crucial to the designer's work at all stages of the fashion production process and are also provided with economic and managerial knowledge necessary for success in the fashion market. It is likewise important to stress that the different aspects of introducing sustainability in fashion design and production identified by the authors and present in the activities of fashion schools (Table 1) may be connected with the development of skills in more than one dimension of design education (e.g., the reasons for the selection and particular use of sustainable fabrics may be motivated by artistic, technological, and/or economic rationales, which are often intertwined). 
Table 1. Main sustainable fashion-related themes present in the activities of schools offering fashion majors in Poland (source: own elaboration).

Main Theme

Specific Sustainability-Related Themes

\section{Frequency of the Appearance of a \\ Given Theme on Social Media and on the Web Pages of Schools \\ (5-Very Frequent, \\ 1-Very Rare)}

\begin{tabular}{|c|c|c|}
\hline \multirow{3}{*}{$\begin{array}{l}\text { Fabrics and textiles as creative inspiration } \\
\text { and as a challenge in terms of sustainable use }\end{array}$} & Deconstruction & 5 \\
\hline & Recycling and upcycling & 5 \\
\hline & $\begin{array}{c}\text { Ecological textiles and technological } \\
\text { solutions (e.g., new fabrics, production } \\
\text { processes, and dyeing) }\end{array}$ & 4 \\
\hline \multirow{3}{*}{$\begin{array}{l}\text { Appreciation for and potential use of local } \\
\text { heritage, including textile and clothing } \\
\text { production traditions }\end{array}$} & $\begin{array}{l}\text { Using local heritage as a design } \\
\text { inspiration (etnodizajn in Polish) [59] }\end{array}$ & 4 \\
\hline & $\begin{array}{l}\text { Locally sourced fabrics and } \\
\text { local production }\end{array}$ & 3 \\
\hline & $\begin{array}{l}\text { Traditional fabrics and fashion } \\
\text { accessories; traditional, environmentally } \\
\text { friendly production processes (e.g., using } \\
\text { only organic ingredients and supplies) }\end{array}$ & 2 \\
\hline \multirow{3}{*}{$\begin{array}{l}\text { Shaping designers' awareness of and } \\
\text { sensitivity to current global problems }\end{array}$} & General sensitivity to global problems & 4 \\
\hline & $\begin{array}{l}\text { Important problems and negative } \\
\text { environmental and social impacts of the } \\
\text { fashion industry, CSR, and ethics in } \\
\text { fashion (people and animals) }\end{array}$ & 3 \\
\hline & $\begin{array}{l}\text { Empathy for and design tailored to the } \\
\text { needs of specific societal and age groups } \\
\text { (e.g., the elderly, the disabled, } \\
\text { and refugees) }\end{array}$ & 1 \\
\hline \multirow[t]{2}{*}{ Designers as sustainability activists } & $\begin{array}{c}\text { Broader sustainability issues as a design } \\
\text { inspiration: 'verbalisation' of global and } \\
\text { local ecological, social, economic, cultural, } \\
\text { and spiritual issues through fashion (e.g., } \\
\text { its form, materials used, slogans on } \\
\text { clothing, etc.) }\end{array}$ & 2 \\
\hline & $\begin{array}{l}\text { Designers' role in educating the general } \\
\text { public and shaping consumption patterns } \\
\text { and consumer attitudes }\end{array}$ & 3 \\
\hline $\begin{array}{l}\text { Designers as informed participants in the } \\
\text { fashion market (entrepreneurs, employees, } \\
\text { employers, and creators of comprehensive } \\
\text { concepts of fashion brands) }\end{array}$ & $\begin{array}{c}\text { Challenges of developing and managing } \\
\text { sustainable fashion businesses } \\
\text { and brands }\end{array}$ & 2 \\
\hline
\end{tabular}

The analysis of activities undertaken in Polish fashion design schools points to their growing interest and involvement in sustainable fashion education as well as to an overall increase in students' knowledge and awareness in this area. In general, the issues, themes, teaching methods, and dilemmas seen as important by Polish fashion schools are in line with those of their Western European or Anglo-Saxon counterparts, namely, technocentric considerations, such as limiting resource use and material waste on the one hand, and eco-centric approaches with broader societal aims on the other.

Not all themes and activity types are present to the same extent in the activities of fashion schools in Poland, however (Table 1). The most frequent, omnipresent theme was fabrics and textiles as creative inspiration and as a challenge for sustainable use, the first sustainable fashion topic to be introduced in Polish education. Another recurring 
theme is the potential of local heritage, including textile and clothing production traditions, connected with the rising popularity of what is called etnodizajn in Poland in recent decades [59]. Taking into account the rather low level of general knowledge on sustainable development and challenges to it in the Polish context, education on current environmental and social challenges facing the fashion industry was the third-most commonly tackled theme. Looking at the potential new roles of fashion designers, their roles as communicators, educators, and activists are perhaps stressed more than those of facilitators and in particular entrepreneurs in the sense of new business solutions. This issue was also noted by interviewed fashion professionals as one that is in need of development.

Similarly, although there is a broad variety of sustainable fashion activities in which fashion schools can and do engage (Table 2), some activity types or forms of sustainable fashion education are used more often than others. In general, Polish fashion schools are more likely to include sustainability themes in extracurricular activities and events, and participate or promote events organised by other institutions rather than include them in official communications and core curriculum. Almost two-thirds of schools that offer fashion majors organise sustainable fashion events aimed at the general public, with the aim of increasing awareness and cooperate with other stakeholders in sustainable fashion initiatives. At over half of the schools analysed, sustainable approaches are visible in student designs developed for particular courses or as a leitmotif of end-of-year or graduation collections. One in two schools promote sustainable fashion events and initiatives of external organisers and participate or encourage their students to take part in external sustainable fashion events and initiatives. A visibly smaller share-less than one-third—of schools publish on sustainable fashion or make the effort to organise specialist sustainable fashion events addressed to students and other fashion professionals. Even fewer-only one in five institutions-include sustainability in their official strategic statements (e.g., MSKPU's mission statement 'Without a healthy ecosystem we have no use for beautiful clothes' is implemented not only in relation to its educational activities but also for activities supporting ecological and ethical behaviours, such as cooperation with and sponsorship of organisations campaigning against fur farming) [60], incorporate sustainable fashion issues in the majority of courses or as a separate course, or make sustainability-oriented activities and events organised at the school compulsory for its students (e.g., LUT opened an exhibition entitled The Nature of Things, Eco or Ego? on the inauguration day of the new academic year, addressed mainly to new students, drawing attention to what is important to the school and what might be the first important question shaping the identity of a future designer) [61].

There are also significant differences in terms of the range of activities that schools engage in depending on school type (Table 3). Specialist private fashion schools are much more likely to include fashion sustainability in a broad array of activities, often making sustainability the leitmotif of the school's activities and image. Public art schools are increasingly highlighting this issue, but their involvement is less comprehensive. Private schools with a broader artistic or general profile and public universities with a broader profile engage in a visibly narrower range of sustainable fashion activities. 
Table 2. Inclusion of references to sustainable fashion in the activities of schools that offer fashion majors in Poland (source: own elaboration).

\section{Activity Type (Dimension of Analysis)}

Percentage of Schools That Inform the General Public of Engagement in a Given Type of Activity

Inclusion of sustainability in official statements or other public

communications (articles, blogs, podcasts, and manifestos)

\section{2}

Sustainability as a visible and promoted leitmotif throughout the curriculum (present in the majority of courses or as a separate course)

Sustainability activities and events organised by the school, compulsory for students
22

22

Activities and events organised by the school (e.g., conferences, workshops, and professional meetings) as an additional/extracurricular

(educational) offer aimed at students or students and other (external)

fashion professionals

Publishing on sustainable fashion 28

Participation of the school (lecturers and students) in sustainable fashion events and initiatives organised by other institutions and organisations in Poland and abroad

Promoting sustainable fashion events and initiatives organised by other (external) bodies

Inclusion of sustainability in student designs (created as assignments for particular courses or as the theme of end-of-year or graduation collections)

Events organised by schools (e.g., workshops) for the general public

(non-specialist participants not connected with the fashion market)

Cooperation with other stakeholders on sustainable fashion initiatives

(other schools, firms in the fashion industry, museums, and

non-governmental organisations)

Table 3. Level of engagement of different school types in sustainable fashion activities (source: own elaboration).

\begin{tabular}{cc}
\hline School Type & $\begin{array}{c}\text { Average Number of Sustainable Fashion Activity } \\
\text { Types a Given School Type Is Involved in (out of 10 } \\
\text { Identified by the Authors) }\end{array}$ \\
\hline Specialist private fashion schools & 8 \\
\hline Public art schools & 4 \\
\hline Private schools with a broader artistic or general profile & 2 \\
\hline Public universities with a broader profile & 2 \\
\hline Average for all schools offering fashion majors & 4 \\
\hline
\end{tabular}

\subsection{Challenges in Sustainable Education of Fashion Designers in Poland}

Fashion schools are proving increasingly capable of unlocking the dormant potential of aspiring designers in terms of creativity and sustainability in fashion design. This does not mean, however, that it is a smooth process. Polish schools experience similar challenges to schools all over the world, such as dilemmas over including sustainable fashion in long-term comprehensive curricula or as extracurricular, elective educational activities, and uncertainty about what to teach and what the impact will be on students' attitudes. There are no systemic solutions on inclusion of sustainability in fashion design curricula, and it is often difficult to assess whether references to it are indeed deeply ingrained in teaching 
practices or merely a sort of educational greenwashing practised in order to appear up to date and attract potential students.

Moreover, the dynamics of emerging eco-trends and new technological and organisational solutions contribute to the growing uncertainty for institutions and teachers. Impulses for change and the substitution of unsustainable with eco-friendly fabrics are constantly emerging. This creates additional problems. It takes time to ascertain their actual properties and performance. The teacher is, therefore, faced with a dilemma between educating students about novelties in the absence of their own experience with the materials and fabrics (e.g., eco-skins made from plants and the problem of their shorter lifespans compared to natural leather, I3).

The visibility of sustainability-related issues in fashion schools is usually highly dependent on the initiative and leadership of particular, often isolated individuals who teach at a given school. Encouraging students to practice sustainable fashion may also be difficult due to the disappearance of traditional textile producers and, in some cases, insufficient stress on craftsmanship skills and their transmission and practical cooperation with other players in the fashion industry. In the Polish context, all three of these issues have become more problematic in recent decades due to the initially delayed but then fast-paced restructuring and offshoring of the textile and clothing industry, in parallel with broader post-socialist transformation processes after 1989.

Several other educational challenges faced by Polish post-secondary fashion design schools in this respect should be mentioned. Significantly, these are linked not only to students' willingness to espouse sustainability principles, or to their skills or attitudes, but also to the wider environment and the national context in which the schools function.

\subsubsection{Lasting Impact on Attitudes and Practices}

The main challenge encountered by schools throughout the education process is to construct the curriculum and develop additional educational opportunities in such a way as to shape long-term responsible attitudes. This may be considered a challenge related to world view: encouraging students to accept and internalise sustainability principles and include them in their value systems, which is necessary if such principles are to be applied, i.e., translated into activities and choices made by particular individuals. Polish private specialist fashion schools seem to be more aware that it is not possible to instil such long-term, deeper attitude changes in every student, but they hope to be able to exert such an impact on as many students as possible by referring to as many sustainability dimensions, issues, and forms of conveying them as possible and 'immersing' students in the subject, creating an atmosphere conducive to espousing sustainable principles and offering knowledge on practical ways of implementing these in professional practice. In educating fashion design professionals, they attempt to shape their broader outlook on life, making them aware of the need for reflection and developing 'positive' links with the environment (many exercises and tasks given to students require self-reflection and individual encounters with issues of responsibility; these exercises are often difficult and emotionally engaging, necessitating engagement beyond the strictly technical aspects of the profession). They require asking many questions and searching for answers (often a tedious and time-consuming task), beginning with the basic issue of what a designer's freedom is, in what dimensions it expresses itself, what its constraints are or should be, and consequently, how this independence can translate into pro-environmental stances and activities.

In many instances, these schools pay attention to offering a value-based education. The designer's mission is presented not only as that of an artist (although this is also important) but also that of a craftsman responsible for the manufactured product and the way it was created, and for the impact of that product on the environment, the consumer, and future generations. Taking a shallow, one-dimensional, or selective approach to sustainable fashion is seen as inappropriate-most often as an expression of the desire to fit in with trends and gain additional customers. Efforts are made to convey to students not only the 
short-sightedness and ecological harm of such an approach, but also its short-lived business value (image loss when a false, superficially ecological approach is exposed). Students are equipped with tools and ways to assess the overall environmental impact of their professional work, taking into account the costs it generates in the most comprehensive way possible (e.g., life-cycle assessment concepts, Hicks index; I4).

Another important issue-a kind of sine qua non for obtaining sustainable educational results in this area-is the coherence of the activities of the school and its staff with the content it teaches. This creates another 'circle' surrounding students with pro-environmental ideas. It is built both on an institutional and personal level, thanks to the individual (often extracurricular) activities of teachers.

The credibility of teachers is built through the strength of the coherence between the educational content they communicate and their own design activities (creating sustainable collections, success in eco-fashion competitions) or other business-oriented, charitable, research, and publication work (including traditional publications, but also media appearances, social media presence, blogging, and vlogging). For instance, a teacher from one of the analysed schools who offers advertising fashion photography services on the Internet states that 'I only cooperate with brands reflecting aesthetics and philosophy consistent with my values. I carry out projects taking care to preserve a consistent brand image, and the credibility of both the party commissioning the project and myself' [62]. The professional activities of all those interviewed for our study are largely consistent with the educational content and self-image they communicate. Students at fashion schools are, therefore, frequently offered an opportunity to immerse themselves in sustainable fashion principles, not only through learning by doing but also through learning by example. However, attention was also drawn to the need for a more comprehensive attitude change in the staff that is educating future designers in Poland. Although practically every school can boast a very active spokesperson involved in promoting sustainable fashion and identifying with it very deeply, this sentiment is not as fervently advanced across the board. The holistic process of creating a new community of responsible designers will be undermined if the messages coming out of different fashion courses and from different teachers at the same school are not consistent (which continues to happen).

Moreover, the responsibility of the educational institution encompasses environmentally friendly activities and solutions that are not directly related to the educational process but simply result from the day-to-day functioning of the school (e.g., purchase of environmentally friendly cleaning products and other consumables), drawing the students' attention to the need to make their consumption behaviour more environmentally friendly (e.g., use and reuse of materials, careful use of equipment so that it is functional for as long as possible, etc.) (I2, I3, I4).

\subsubsection{The Need for a Holistic Approach}

Lecturers at fashion schools emphasise that as much as it is necessary to provide students with possibilities to develop the different skills required to become a successful fashion designer, there is also a need to apply a holistic, multidimensional approach to the problem of fashion sustainability. Such a comprehensive approach is necessary, because while overall levels of ecological awareness are increasing and many people are well educated in sustainability and eco-responsibility, at the same time, much knowledge and information is still fragmentary, shallow, and superficial, in particular in terms of real, effective solutions to the sustainability problems of the contemporary fashion market. Superficiality may be a bigger threat than lack of knowledge or ignorance because it creates the illusion of understanding the subject.

Supplying shocking data and images, 'bombarding' students with difficult topics, and pointing out the consequences of individual and corporate irresponsibility may change the attitudes of many. Sometimes, this involves transformation from one extreme to the other, from a vision of oneself as a designer of a luxury brand 'surrounded by sexy women and well-groomed men, the world of posing against a glossy photography backdrop, to the 
new concept of low-cost design with a minimal environmental impact after experiencing a sort of catharsis' (I2). Interestingly, universities do not limit students' choices of where to intern, and there is a deep wisdom hidden in this attitude, where personal reflections on the fashion market are generated through experience rather than verbal messages in classes (e.g., students interning in fashion corporations are free to decide to accept and develop or reject this career path) (I3).

The teaching methods and reflections of the interviewed teachers repeatedly reflected the wisdom of experienced educators, who know that they should teach all aspects of sustainability while acknowledging that usually only selected issues will be noticed by particular students. Thus, teaching does not always produce spectacular effects, such as complete changes in attitude. It is considered a success to evoke reactions that prompt a young designer to incorporate at least one of the many aspects of sustainability in the fashion market into their future work-hence, the differential stimulation of students, inspiring their personal and professional search for solutions in many forms and directions, suggesting how to make the fashion market more sustainable. Sometimes, this realistic approach manifests itself in surprising topics, where fast fashion, by definition unsustainable, plays a central role. Together with students, lecturers look for ways to extend the longevity and flexibility of fashion, to adapt to changing needs, or to combine fast fashion with vintage fashion (I4, I5). For instance, it was noted that most consumers already have products by major fast fashion brands in their closets, and thus, one dimension of the sustainable approach to fashion is to match newly designed, ecological, and sustainable clothes with the things they already possess, so that they do not become unnecessary waste. If, on the other hand, the client wants to get rid of some of the clothes they already own, it is the designer's or stylist's task to suggest methods of sustainable disposal (e.g., selling them, giving them to the needy or to a charitable organisation, or organising mini-swaps among friends) (I5).

\subsubsection{Awareness and Attitudes of the General Public}

Sustainable fashion design education in Poland takes place in a more challenging context than in many other countries due to the low level of ecological and sustainability awareness in the general public. Overall, sustainability is still not a very important issue for Polish customers [26,41]. They may support the vague idea of sustainable fashion, but may not fully grasp the multidimensionality of the challenge and may display distrust of the intentions and credibility of designers and fashion firms introducing sustainability into their activities, or display an attitude-purchase behaviour gap [29].

Designers who intend to operate on the Polish market should also take note of the diverse challenges and possibilities peculiar to different age brackets of the fashion market, particularly visible in the post-communist context. Western fashion consumers have been taught about sustainable consumption for longer and successively [28]. Older consumers in Poland may be prone to overconsumption or excessive purchases, stressing quantity over quality as a reaction to previous experiences of a shortage economy, but may also have limited purchasing power, appreciate durability, and possess well-developed and ingrained competencies in terms of the longevity of clothing use and its maintenance, which can be an inspiration and a source of knowledge for young designers and could be (in some cases already is) exploited in fashion design education [28]. Younger generations that do not have first-hand experience of the limitations of the communist times may in turn be more prone to follow new trends and be fast-fashion consumers, but are in general more open to new information and more aware of ecological challenges. They also look for ways to make their consumption unique. The growing popularity of vintage fashion among young people in Poland is a good example of this [26].

The need to shape conscious, responsible consumers from the earliest stages of education-largely neglected in Poland and resulting in the need to catch up (often only) in adulthood-came up repeatedly as a conclusion (I3). Schools respond to this problem within their capabilities through a number of activities popularising eco-fashion among 
consumers, such as through events and eco-fashion shows in urban spaces (I5). For instance, the Fashion Promotion Centre at SAAL organises EcoMake, an event that includes exhibitions, a competition, fashion shows, seminars, workshops, and other actions. Schools also participate in open public debates. An example is the discussion on ecology in fashion as a part of the event 'Designed in Krakow-Meetings with Design 2020' co-organised by CSAFD (the school's lecturers, invited journalists, fashion critics, artists, and influencers participated in the debate).

Schools conduct activities that teach the general public (consumers) practical skills (e.g., sewing courses and alteration of clothes), and they provide information and develop knowledge by organising open lectures and meetings about responsible consumption (e.g., you will not be responsible if you buy more ecologically produced clothes than you need and you can be responsible by buying cheap clothes if you cannot afford others, and then using them for a long time, recycling or reviving them in an appropriate way) (e.g., MSKPU, CSAFD, SAAL, LUT, AAS, SF, LSAD, and HTS in Katowice). Using the potential of their spaces, fashion schools organise events encouraging people to exchange their clothes (e.g., Autumn Swap at SF) or to participate in events where sustainably produced wares are sold (e.g., VIAMODA's pre-Christmas Slow Weekend fair). Promoting the circularity of clothes that have already been produced needs to be particularly popularised in Poland, as in many places (and especially outside big cities), there is still a stigmatisation of second-hand stores as places that supply clothes to the poorest, disadvantaged social groups.

Schools interact with their environment when they see the need for change (e.g., they appeal to public authorities and major fashion corporations, expose greenwashing, etc.). Their aim is to induce a domino effect through their actions, where a change in individual attitudes engenders changes in broader social groups (e.g., students who change their attitudes towards fashion may in time also educate their friends and families; I2). As mentioned earlier, in the Polish context, fashion schools have a special job to do in this respect, as the level of awareness of sustainability challenges connected with fashion, both among customers and among fashion designers, is still low and is coupled with the existing barriers to entering the market and a simultaneous lack of comprehensive public support (in particular legal, promotional, and financial at the national level) for sustainable fashion. This is why many institutions try to support their graduates embarking on careers, strengthening their position in the market by promoting their creative ideas, brands, and collections at university events and on social media, reporting their successes and awards (CSAFD, MSKPU, SF), or providing them with exhibition space (e.g., AFAK, LUT).

\subsubsection{Institutional Context and Possibilities for Cooperation with External Partners}

An analysis of the institutional conditions for implementing education on sustainable fashion in the Polish context reveals several country-specific problems in this regard. First of all, there is a significant disproportion in the capacity of particular universities in terms of human, infrastructural, and financial potential, but also in terms of the way the institutions function.

The staff of private schools consists, to a larger extent than in the case of public ones, of practitioners who are professionally active in the fashion market in its various dimensions and aspects (owners of independent fashion brands, designers, stylists, journalists, etc.). Lecturers at public institutions (mainly academies of fine art) more often tend to be focused on pursuing academic careers and theoretical reflection or design with purely artistic aims. Although this does not preclude the presence of staff actively practising commercially oriented designer professions at public schools or teachers involved in academic pursuits and gaining academic degrees at private ones, the proportions of 'practitioners' versus 'academics' in the two types of schools seems to be inverse.

Both types of schools function in different organisational and institutional environments. Due to their different operating models, they may vary in terms of their effectiveness in establishing fruitful cooperation with other actors in the fashion market and responding quickly to changes in educational needs. In general, it is much easier for private schools 
to make rapid changes and adjustments to their curricula, such as incorporating newly emerging aspects of sustainable fashion into individual course syllabuses.

Fashion schools cooperate with the industry for a variety of reasons: to seek support and inspiration regarding trends and their variability, as well as market, technological, and organisational innovations. In both types of schools, however, this is subject to completely different procedures and patterns of collaboration. It is much easier for private institutions to enter into more spontaneous relations, while public universities are often bound to extensive bureaucratic and organisational procedures that increase the time it takes to organise events, establish cooperation, develop joint ventures, and obtain funding.

The analysis of Polish schools also shows that certain economies of scale are possible in the case of larger universities with more complex organisational structures, regardless of their ownership. When one institution offers various fields of study linked with design, more often than not, numerous initiatives are developed that simply promote sustainable, modern design (e.g., Design Zone at the SWPS University, which includes the SF).

Regardless of the legal and organisational structure of a given school, the institutions under analysis can, and in practice do, benefit from the potential of activities and initiatives proposed by or co-organised with external partners, in particular for exhibitions, competitions, and workshops, where students have the opportunity to learn about new trends, present their designs, and observe changes taking place in the market. Our analysis revealed numerous instances of such cooperation. For example, students of VIAMODA took part in the Fashioning Sustainability competition organised by Freudenberg Performance Materials, while students of HTS in Katowice participated in the Biennale Internationale Design de Saint-Ėtienne, where they staged an exhibition entitled Artistic elements in designintegration of fine arts and architecture in the context of Polish folklore [63]. Students from UA in Poznań participated in workshops, learnt about new technologies, and created lookbooks as part of the Fashioning Sustainability workshop at the International Fair of Sustainable Fashion NEONYT2019 organised by Freudenberg Performance Materials. Students and graduates of SAAL exhibited their design ideas in an exhibition called Future Man 2052 during the Brussels Design Conference, as a part of the Brussels Design September in 2020 [64]. AFAK and LUT encourage their students to take part in Modetics, a competition on ethical fashion organised by the French Institute in Poland, while CSAFD encourages its students and graduates to take part in the international EcoChic Design Award competition. Polish schools training fashion designers have also joined international events and initiatives promoting responsible fashion. For example, the partners of the Sustainable Fashion Awards-a competition showcasing socially and environmentally responsible designers and brands-include schools such as the AFAW, AAS, AFAK, CSAFD, MSKPU, UAP, LSAD, VIAMODA, SF, and FS (i.e., ten of the eighteen post-secondary fashion schools identified in Poland).

Fashion schools invite a range of external bodies and institutions to support them in sustainable fashion education (e.g., foundations, management experts, local fashion brands, major fashion brands, and retailers; I3). Their staff and students engage in events that look at the economic aspects of the work of a fashion designer, whether they are running their own brand or working for a large company. For example, the SAAL promoted discussions and events within the framework of the Modopolis Forum of Polish Fashion. The event was attended by active designers who talked about the difficulties-both technical and organisational-of creating sustainable fashion in Poland and arising out of particular consumer needs and expectations. During this event, issues such as how to manage the process of developing a business strategy and how to implement it in an optimal way were discussed. The event also offered participants an opportunity to learn more about the development of effective fashion communication (e.g., the workshops 'How to live well with Uncle Google' and 'How to build a transparent brand') [65]. Naturally, developments in Poland also take place in reaction and in reference to wider, global trends in the fashion market and in terms of curricula and teaching initiatives observed in major fashion schools across the world. The global circulation of publications and reports, exchanges and study 
visits of students and staff to universities abroad, and joint projects on sustainable fashion with foreign partners all contribute to the spread of approaches to sustainable fashion education in a more peripheral national fashion context such as Poland (I3, I4 I5, I7). For instance, the involvement of Polish fashion schools in the international discourse will be visible in October 2021, when the AFAW acts as the main organiser and (virtual) venue of the Global Fashion Conference (I3).

\subsubsection{Availability of Educational Materials}

One recurring issue encountered in sustainable fashion education in the Polish context is the availability of educational materials in Polish. The interviewees emphasised that the most up-to-date textbooks and other materials, often available free of charge, are in English. Despite the fact that the language competencies of students in Poland are constantly improving, insufficient knowledge of English is still a barrier for some to a constant learning process and effective quest for inspiration. To overcome this challenge, some teachers prepare their own texts and handouts in Polish, drawing on international reports. In one case, the frustration with the lack of Polish-language teaching materials for a particular course led to the publication of the first textbook on fashion ethics in Polish, authored by M. Płonka, the director of MSKPU, and entitled "Ethics in Fashion. CSR in the Garment Industry" [57] (I4).

\subsubsection{Availability of Sustainable Fabrics and Other Supplies}

Another problem evident in the Polish context is the limited availability of sustainably produced fabrics and sewing and tailoring accessories. Students who want to use these in their designs, therefore, incur an increased cost to obtain them, often importing them from abroad (where they are already more expensive than standard materials). It should be noted, however, that many students overcome this problem with their own determination and creativity (e.g., by making accessories from ecological materials or dyeing fabrics ecologically on their own, and recycling and upcycling materials).

\section{Perspectives and Closing Remarks}

Trends and the changing conditions of the contemporary fashion market create a pressure to constantly adjust and transform the curricula of fashion design education at the post-secondary level. This change is indispensable if future fashion graduates are to gain the necessary knowledge, skills, and competences for the sustainable design and production of garments and to shape the attitudes of fashion consumers [50]. The final effect of their creative efforts should not only be aesthetically pleasing and well made (quality) but also convincingly marketed to customers. The end product should, in a way, be an emanation of the 'sustainable mindset' developed by the well-educated fashion designer. This is not an easy task, and requires long-term and multidimensional work on the sensitivity and awareness of young creatives, and on their skills, while at the same time making them aware of the growing non-aesthetic requirements and challenges connected with fashion design and production. Fashion design educators should also include in their approach the issue of the values represented by both garments and the creatives themselves, as well as the increasing competition both in terms of price (fast fashion), and resulting from the ever more complex marketing techniques applied not only by the biggest players in the market but also by firms with a more regional or local market range. This educational challenge-difficult and risky in terms of its chances of success-is undertaken by Polish fashion design schools without, or at most with very limited and uncoordinated, public, legal, and financial support. Moreover, if on the one hand aspiring Polish designers are increasingly ecologically aware, on the other, under closer scrutiny, the true depth of this knowledge can be called into question-often due to insufficient sustainability-related education at earlier stages of education in the Polish system. Another recently emerging factor that has complicated the already difficult process of the formation of the sustainable fashion designer is the impact of the COVID-19 pandemic, on both the demand and supply 
sides of the fashion market. In the post-COVID world, will we continue on the road towards an economy of values, or will we return to business as usual?

Author Contributions: Conceptualization, M.M.-K. and D.H.; methodology, M.M.-K. and D.H.; validation, M.M.-K. and D.H.; formal analysis, M.M.-K. and D.H.; investigation, M.M.-K. and D.H.; resources, M.M.-K. and D.H.; writing — original draft preparation, M.M.-K. and D.H.; writing-review and editing, M.M.-K. and D.H.; visualization, M.M.-K. and D.H.; project administration, M.M.-K.; funding acquisition, M.M.-K. All authors have read and agreed to the published version of the manuscript.

Funding: This research was funded by the Polish National Science Centre, grant "Fashion market in the context of sustainable development", grant agreement no. UMO-2018/31/B/HS4/02961 for the years 2019-2023.

Acknowledgments: The authors would sincerely like to thank all fashion educators who took part in the interviews conducted as part of this project. The interesting comments and suggestions of the three reviewers of the paper are also much appreciated.

Conflicts of Interest: The authors declare no conflict of interest.

\section{References}

1. Gwilt, A.; Rissanen, T. (Eds.) Shaping Sustainable Fashion. Changing the Way We Make and Use Clothes; Earthscan: London, UK, 2011.

2. Fletcher, K. Sustainable Fashion and Textiles. Design Journeys; Earthscan, Routledge: Abingdon, UK, 2014.

3. Niinimäki, K. Sustainable Fashion in a Circular Economy. In Sustainable Fashion in a Circular Economy; Niinimäki, K., Ed.; Aalto University School of Arts, Design and Architecture: Espoo, Finland, 2018; pp. 12-41. Available online: https://core.ac.uk/ download/pdf/301138773.pdf (accessed on 10 June 2021).

4. Thomas, S. Fashion Ethics; Routledge: London, UK, 2018.

5. Fletcher, K.; Grose, L. Fashion and Sustainability: Design for Change; Laurence King: London, UK, 2012.

6. Gwilt, A. A Practical Guide to Sustainable Fashion; Bloomsbury: London, UK, 2014.

7. Henninger, C.E.; Alevizou, P.J.; Goworek, H.; Ryding, D. (Eds.) Sustainability in Fashion. A Cradle to Upcycle Approach; Palgrave Macmillan: Cham, Switzerland, 2017.

8. Roos, S.; Sandin, G.; Zamani, B.; Peters, G.; Svanström, M. Will clothing be sustainable? Clarifying sustainable fashion. In Textiles and Clothing Sustainability. Implications in Textiles and Fashion; Muthu, S.S., Ed.; Springer: Singapore, 2017; pp. 1-45.

9. D'Adamo, I.; Lupi, G. Sustainability and Resilience after COVID-19: A Circular Premium in the Fashion Industry. Sustainability 2021, 13, 1861. [CrossRef]

10. Peters, G.; Li, M.; Lenzen, M. The need to decelerate fast fashion in a hot climate-A global sustainability perspective on the garment industry. J. Clean. Prod. 2021, 295, 126390. [CrossRef]

11. Grose, L. Fashion design education for sustainability practice. Reflections on undergraduate level teaching. In Sustainability in Fashion and Textiles. Values, Design, Production and Consumption; Gardetti, M.A., Torres, A.L., Eds.; Routledge/Green Leaf Publishing: London, UK, 2013; pp. 134-147.

12. Fletcher, K. Design for sustainability in fashion and textiles. In The Handbook of Fashion Studies; Black, S., de la Haye, A., Entwistle, J., Rocamora, A., Root, R.A., Thomas, H., Eds.; Bloomsbury: London, UK, 2013; pp. 557-574.

13. Williams, D. Fashion design. In The Routledge Handbook of Sustainability and Fashion; Fletcher, K., Tham, M., Eds.; Routledge: London, UK, 2015; pp. 234-242.

14. Fuad-Luke, A. 'Slow Design': A paradigm Shift in Design Philosophy? In Proceedings of the Design by Development (dyd02) 2nd International Conference on Open Collaborative Design for Sustainable Innovation, Bangalore, India, 1-2 December 2002.

15. Ræbild, U. From Fashion Pusher to Garment Usher? How Fashion Design Students at Design School Kolding Currently Explore their Future Role in Society. In Soft Landing: Cumulus Think Tank Publication No. 3; Nimkurlat, N., Raebild, U., Piper, A., Eds.; Aalto University, School of Arts, Design and Architecture: Helsinki, Finland, 2018; pp. 113-126. Available online: https:/ /www.cumulusassociation.org/wp-content/uploads/2018/04/PDF_SINGLE_cumulus_soft_landing.pdf (accessed on 10 June 2021).

16. Earley, R. The New Designers: Working Towards Our Eco Fashion Future. In Proceedings of the Dressing Rooms: Current Perspectives on Fashion and Textiles Conference, Oslo, Norway, 14-16 May 2007.

17. Sousa, G.; Simoes, I. Fashion Design and Entrepreneurship: A Strategic Model for Higher Education in Portugal. In Proceedings of the Virtuous Circle, Summer Cumulus Conference, Milan, Italy, 3-7 June 2015.

18. Faerm, S. Building best practices for fashion design pedagogy: Meaning, preparation, and impact the increasingly volatile professional world for which students must be trained. Cuaderno 2015, 53, 189-213.

19. Cleverdon, L.; Pole, S.; Weston, R.; Banga, S.; Tudor, T. The Engagement of Students in Higher Education Institutions with the Concepts of Sustainability: A Case Study of the University of Northampton, in England. Resources 2017, 6, 3. [CrossRef] 
20. Designing for a circular economy: Lessons from the great recovery 2012-2016; Royal Society for the Encouragement of Arts, Manufacturers and Commerce: London, UK, 2016. Available online: https://www.thersa.org/globalassets/pdfs/reports/the-greatrecovery---designing-for-a-circular-economy.pdf (accessed on 2 April 2021).

21. Onur, D.A. Integrating Circular Economy, Collaboration and Craft Practice in Fashion Design Education in Developing Countries: A Case from Turkey. Fash. Pract. 2020, 12, 55-77. [CrossRef]

22. Leerberg, M.; Riisberg, V.; Boutrup, J. Design Responsibility and Sustainable Design as Reflective Practice: An Educational Challenge. Sust. Dev. 2020, 18, 306-317. [CrossRef]

23. Fletcher, K.; Williams, D. Fashion education in sustainability in practice. RJTA 2013, 17, 81-88. [CrossRef]

24. Bertola, P. Reshaping Fashion Education for the 21st Century World. In Soft Landing: Cumulus Think Tank Publication No. 3; Nimkurlat, N., Raebild, U., Piper, A., Eds.; Aalto University, School of Arts, Design and Architecture: Helsinki, Finland, 2018; pp. 7-15. Available online: https://www.cumulusassociation.org/wp-content/uploads/2018/04/PDF_SINGLE_cumulus_soft_ landing.pdf (accessed on 10 June 2021).

25. Salolainen, M.; Leppisaari, A.-M.; Niinimäki, K. Transforming Fashion Expression through Textile Thinking. Arts 2019, 8, 3. [CrossRef]

26. Bhandari, V. Future of Fashion Education in India-Focus and Emerging Scenarios. In Soft Landing: Cumulus Think Tank Publication No. 3; Nimkurlat, N., Raebild, U., Piper, A., Eds.; Aalto University, School of Arts, Design and Architecture: Helsinki, Finland, 2018; pp. 17-23. Available online: https://www.cumulusassociation.org/wp-content/uploads/2018/04/PDF_SINGLE_ cumulus_soft_landing.pdf (accessed on 10 June 2021).

27. Finn, A.L.; Fraser, K. The Big Picture: An Integrated Approach to Fashion Design Education. In Proceedings of the Fashion Industry New Zealand (FINZ) Annual Education Conference: The Broader Perspective of Design, Wellington, New Zealand, 8-10 August 2007; Unpublished.

28. Raciniewska, A. When ethical fashion is a challenge: Polish case. In Fashion and Its Multi-Cultural Facets; Hunt-Hurst, P., Ramsamy-Iranah, S., Eds.; Interdisciplinary Press: Oxford, UK, 2014; pp. 139-148.

29. Koszewska, M.; Rahman, O.; Dyczewski, B. Cricular fashion-Consumers' attitudes in cross-national study: Poland and Canada. AUTEX Res. J. 2020, 20, 327-337. [CrossRef]

30. Reif, R.; Zalewska, K.; Suchecki, K.; Kin, K. Czy Ekologia jest w Modzie. Raport o Odpowiedzialnej Konsumpcji i Zrównoważonej Modzie $w$ Polsce; Accenture: Warszawa, Poland, 2020.

31. D'Itria, E. Fashion design education and sustainability. A challenge accepted. In Proceedings of the 3rd LeNS World Distributed Conference: Designing Sustainability for All; Ambrosio, M., Vezzoli, C., Eds.; Edizioni POLI.design: Milano, Italy, 2019; Volume 4, pp. 1303-1308.

32. Black, S. Editorial. Fash. Pract. 2009, 1, 5-8. [CrossRef]

33. Payne, A.; Ibanez, I.; Pearson, L. New Materiality: "Making Do" and Making Connections. In Soft Landing: Cumulus Think Tank Publication No. 3; Nimkurlat, N., Raebild, U., Piper, A., Eds.; Aalto University, School of Arts, Design and Architecture: Helsinki, Finland, 2018; pp. 35-50. Available online: https://www.cumulusassociation.org/wp-content/uploads/2018/04/PDF_SINGLE_ cumulus_soft_landing.pdf (accessed on 10 June 2021).

34. Rissanen, T. Fashion design education as leadership development. In Proceedings of the Global Fashion Conference 2018, London, UK, 31 October-1 November 2018.

35. Acevedo-Duque, Á.; Gonzalez-Diaz, R.; Vargas, E.C.; Paz-Marcano, A.; Muller-Pérez, S.; Salazar-Sepúlveda, G.; Caruso, G.; D'Adamo, I. Resilience, Leadership and Female Entrepreneurship within the Context of SMEs: Evidence from Latin America. Sustainability 2021, 13, 8129. [CrossRef]

36. Obregon, C. Sustainable Fashion Education: From Trend to Paradigm? Master's Thesis, The Department of Fashion and Clothing Desig, Aalto University School of Arts, Design \& Architecture, Helsinki, Finland, 2012. Available online: https: / / core.ac.uk/download/pdf/80705234.pdf (accessed on 10 June 2021).

37. Nimkurlat, N.; Raebild, U.; Piper, A. Introduction. In Soft Landing: Cumulus Think Tank Publication No. 3; Nimkurlat, N., Raebild, U., Piper, A., Eds.; Aalto University, School of Arts, Design and Architecture: Helsinki, Finland, 2018; pp. 1-4. Available online: https:/ / www.cumulusassociation.org/wp-content/uploads/2018/04/PDF_SINGLE_cumulus_soft_landing.pdf (accessed on 10 June 2021).

38. Smal, D.; Harvey, N. The Wheel: A Teaching Tool for Fashion Design Students. In Proceedings of the Global Fashion Conference 2018, London, UK, 31 October-1 November 2018.

39. Ferrara, M. Smart Experience in Fashion Design: A Speculative Analysis of Smart Material Systems Applications. Arts 2019, 8, 4. [CrossRef]

40. Gam, H.J.; Banning, J. Teaching Sustainability in Fashion Design Courses through a Zero-Waste Design Project Clothing and Textiles. Res. J. 2020, 38, 151-165. [CrossRef]

41. Wubs, B.; Lavanga, M.; Darpy, D.; Depeyre, C.; Segreto, L.; Popowska, M. RE-FRAME FASHION Report. Innovation in Fashion Education; Erasmus University Rotterdam: Rotterdam, The Netherlands; Université Paris-Dauphine: Paris, France; Gdańsk University of Technology: Gdańsk, Poland, 2020; REFRAME FASHION Publications, Erasmus+ Strategic Partnerships for Higher Education Programme of the European Union.

42. Bill, A. "Blood, Sweat and Shears": Happiness, Creativity, and Fashion Education. Fash. Theory 2012, 16, 49-65. [CrossRef] 
43. Rissanen, T. The fashion system through a lens of zerowaste fashion design. In The Routledge Handbook of Sustainability and Fashion; Fletcher, K., Tham, M., Eds.; Routledge: London, UK, 2015; pp. 201-209.

44. Tham, M. Futures of futures studies in fashion. In The Routledge Handbook of Sustainability and Fashion; Fletcher, K., Tham, M., Eds.; Routledge: London, UK, 2015; pp. 283-292.

45. Rissanen, T. Possibility in Fashion Design Education: A Manifesto. Utop. Stud. 2018, 28, 528-546. [CrossRef]

46. Augustyn, M. Crossroads-O relacjach mody z innymi dziedzinami. Tuba 2020, 15, 12-13.

47. The Student Group of Sculpture at the UAP in Poznań. Available online: https://uap.edu.pl/uczelnia/wydzialy/wydzialrzezby/kolo-naukowe-rzezby / (accessed on 31 March 2021).

48. The Academy of Fine Arts in Warsaw. Available online: https://www.facebook.com/385915461962/posts/10157276932071963/ (accessed on 13 March 2021).

49. Trendstudio. Available online: https://trendstudio.pl/ (accessed on 10 April 2021).

50. Pereira, L.; Carvalho, R.; Dias, Á.; Costa, R.; António, N. How Does Sustainability Affect Consumer Choices in the Fashion Industry? Resources 2021, 10, 38. [CrossRef]

51. Siałkowski, K. Wyjątkowy pokaz mody w Warszawie. "Futra nosza piękne zwierzęta i bardzo brzydcy ludzie”. Gazeta 2019. Available online: https: / / warszawa.wyborcza.pl/warszawa/7,54420,25416190,wyjatkowy-pokaz-mody-w-warszawie-futranosza-piekne-zwierzeta.html (accessed on 16 April 2021).

52. Viva! Foundation. Available online: https://viva.org.pl/ (accessed on 16 April 2021).

53. Rosińska, M. Przemyśleć u/życie. Projektanci. Przedmioty. Życie Społeczne; Bęc Zmiana: Warszawa, Poland, 2009.

54. The Statute of VIAMODA. Available online: https://www.viamoda.edu.pl/o-uczelni/akty-prawne_s_60.html (accessed on 4 May 2021).

55. Information on Lectures on the VIAMODA. Available online: https:/ / www.viamoda.edu.pl/ (accessed on 7 June 2021).

56. Harel. Znajdź różnice-ostatnia dekada w polskiej modzie. Tuba 2016, 11, 10.

57. Płonka, M. Etyka w Modzie—CSR w Przemyśle Odzieżowym; Em pe Studio Design: Warszawa, Poland, 2013.

58. Larmuth, M. Artisan. Tuba 2018, 12, 47.

59. Klekot, E. The Seventh Life of Polish Folk Art and Craft. Etnološka Trib. 2010, 33, 71-85.

60. MSKPU. Available online: https://mskpu.pl/2020/02/08/edukujemy-w-zakresie-srodowiska-naturalnego-oraz-dzikozyjacych-zwierzat/ (accessed on 8 June 2021).

61. LUT. Available online: https:/ / www.zu.p.lodz.pl/eko-czy-ego (accessed on 8 June 2021).

62. Natalia Penar Fashion Stylist. Available online: https:/ / nataliapenar.com/fashioninfluencer/ (accessed on 12 June 2021).

63. HTS in Katowice. Available online: http://www.wst.com.pl/news/biennale_internationale_design_saint_tienne-15_03_19/699 (accessed on 17 June 2021).

64. The Strzemiński Academy of Art Lodz. Available online: https://www.asp.lodz.pl/index.php/pl/o-akademii/wystawy/12 -inne-wystawy/1629-future-man-2052 (accessed on 21 June 2021).

65. Modopolis-Forum of Polish Fashion. Available online: http://modopolis.pl/jak-dobrze-zyc-z-wujkiem-google-warsztat-online/ (accessed on 11 June 2021). 